\title{
The Functional Characterization of Podosphaera xanthii Candidate Effector Genes Reveals Novel Target Functions for Fungal Pathogenicity
}

\author{
Jesús Martínez-Cruz,, ${ }^{1}$ Diego Romero, ${ }^{1}$ Fernando N. de la Torre, ${ }^{2}$ Dolores Fernández-Ortuño, ${ }^{3}$ \\ Juan A. Torés, ${ }^{3}$ Antonio de Vicente, ${ }^{1}$ and Alejandro Pérez-García ${ }^{1,+}$ \\ ${ }^{1}$ Departamento de Microbiología, Facultad de Ciencias, Universidad de Málaga and Instituto de Hortofruticultura Subtropical y \\ Mediterránea "La Mayora"-Universidad de Málaga-Consejo Superior de Investigaciones Científicas (IHSM-UMA-CSIC), 29071 \\ Málaga, Spain; ²Departamento de Biología Molecular y Bioquímica, Facultad de Ciencias, Universidad de Málaga, 29071 \\ Málaga, Spain; and ${ }^{3}$ Instituto de Hortofruticultura Subtropical y Mediterránea "La Mayora"-Universidad de Málaga-Consejo \\ Superior de Investigaciones Científicas (IHSM-UMA-CSIC), 29750 Algarrobo-Costa, Málaga, Spain
}

Accepted 5 March 2018.

\begin{abstract}
Podosphaera xanthii is the main causal agent of powdery mildew disease in cucurbits. In a previous study, we determined that $P$. xanthii expresses approximately 50 Podosphaera effector candidates (PECs), identified based on the presence of a predicted signal peptide and the absence of functional annotation. In this work, we used host-induced gene silencing (HIGS), employing Agrobacterium tumefaciens as a vector for the delivery of the silencing constructs (ATM-HIGS), to identify genes involved in early plantpathogen interaction. The analysis of seven selected PEC-encoding genes showed that six of them, PEC007, PEC009, PEC019, $P E C 032, P E C 034$, and PEC054, are required for $P$. xanthii pathogenesis, as revealed by reduced fungal growth and increased production of hydrogen peroxide by host cells. In addition, protein models and protein-ligand predictions allowed us to identify putative functions for these candidates. The biochemical activities of PEC019, PEC032, and PEC054 were elucidated using their corresponding proteins expressed in Escherichia coli. These proteins were confirmed as phospholipid-binding protein, $\alpha$-mannosidase, and cellulose-binding protein. Further, BLAST searches showed that these three effectors are widely distributed in phytopathogenic fungi. These results suggest novel targets for fungal effectors, such as host-cell plasma membrane, host-cell glycosylation, and damage-associated molecular pattern-triggered immunity.
\end{abstract}

Podosphaera xanthii is the main causal agent of cucurbit powdery mildew disease, causing a significant reduction in the quality and quantity of crop yields (Martínez-Cruz et al. 2014). Powdery mildew fungi (order Erysiphales) are obligate biotrophs capable of producing diseases on hundreds of

${ }^{\dagger}$ Corresponding author: Alejandro Pérez-García; E-mail: aperez@uma.es

Funding: This study was supported by grants from the "Agencia Estatal de Investigación (AEI)" (AGL2013-41939-R and AGL2016-76216-C2-1-R), both co-financed by FEDER funds (European Union). J. Martínez-Cruz was supported by a Ph.D. fellowship from the FPI program of the former "Ministerio de Ciencia e Innovación" (MICINN). D. Romero was funded by the "Ministerio de Economía y Competitividad (MINECO)" Ramón y Cajal program (RyC-2011-080605).

*The $\boldsymbol{e}$-Xtra logo stands for "electronic extra" and indicates that six supplementary figures and one supplementary table are published online.

@ 2018 The American Phytopathological Society monocotyledonous and dicotyledonous species worldwide (Dean et al. 2012; Glawe et al. 2008). To date, there are more than 900 described species of powdery mildew (Hacquard 2014). These pathogens develop a specialized structure within the host cells called haustorium, establishing an intimate relationship with its host cell (Caillaud et al. 2014; Martínez-Cruz et al. 2014). This structure is responsible for both nutrient uptake and factor exchange with the plant cell (Lo Presti et al. 2015; Martínez-Cruz et al. 2014; Nowara et al. 2010). Among these factors are the effectors, proteins secreted by the pathogen responsible for modulating the defense response of the plant and, in general, for providing a suitable environment for pathogen development (Ahmed et al. 2015; de Jonge et al. 2011; Lo Presti et al. 2015; Pennington et al. 2016; Pliego et al. 2013); thus, they are receiving considerable attention.

Recently, with the sequencing of genomes and transcriptomes of several powdery mildew species such as Blumeria graminis ff. spp. hordei and tritici, Golovinomyces orontii, and Erysiphe necator, the number of effector candidate genes identified has increased considerably. However, many of them still have no identified function or homology (Jones et al. 2014; Menardo et al. 2017; Pedersen et al. 2012; Spanu et al. 2010; Vela-Corcía et al. 2016; Weßling et al. 2014; Wicker et al. 2013). Thus, the need has emerged to identify the function of this large repertoire of effector candidates with unknown function to understand the molecular mechanisms operating in these biotrophic pathogens to cause disease. Unfortunately, the methods commonly employed for the functional analysis of selected candidate genes in other filamentous fungi cannot be applied to powdery mildews because of their particular lifestyle (MartínezCruz et al. 2017; Vela-Corcía et al. 2015).

Several methods have been developed and proposed for the transformation of powdery mildew fungi, including particle bombardment, electroporation, and Agrobacterium-mediated transformation (Chaure et al. 2000; Christiansen et al. 1995; Martínez-Cruz et al. 2017; Vela-Corcía et al. 2015). However, due to their lifestyles, the genetic manipulation of these pathogens has important limitations, because mutation or knockout of effectors can cause the loss of virulence and it thus becomes impossible to maintain the fungal derivative on living plant material (Nowara et al. 2010). Therefore, the study of effectors in obligate biotrophs required the development of adapted methodologies for the functional analysis of powdery mildew genes. 
RNA interference (RNAi) is an important tool for gene silencing in various organisms (Govindarajulu et al. 2015). Based on this, the host-induced gene silencing (HIGS) system has emerged as a powerful tool to study powdery mildew genes (Nowara et al. 2010; Nunes and Dean 2012). This method is based on the close interaction that the pathogen maintains with the host, through which specific small RNAi produced by the plant after the expression of double-stranded RNA is transferred into the fungus across the haustorium, triggering the degradation of target messenger RNA sequences and resulting in the knockdown of protein expression (Govindarajulu et al. 2015; Nowara et al. 2010; Nunes and Dean 2012; Pliego et al. 2013). In Blumeria graminis f. sp. hordei, to date, 126 effector candidate genes have been examined by HIGS, and 13 have been identified to play an important role in fungal pathogenesis (Ahmed et al. 2015, 2016; Nowara et al. 2010; Pliego et al. 2013; Zhang et al. 2012). Among them, two were identified as ribonucleases and another two were found to interact with a pathogenesis-related protein, glutathione $S$-transferase, malate dehydrogenase, an elongation factor 1 gamma, or a small heatshock protein (Ahmed et al. 2015, 2016; Pennington et al. 2016; Pliego et al. 2013; Zhang et al. 2012). In these reports, however, HIGS analysis was conducted by biolistics, a transformation technique that requires costly special equipment and presents numerous disadvantages, such as low transformation efficiency and damage to plant cells (Harwood et al. 2009; Sanford 1990).

In a previous study, the epiphytic transcriptome of $P$. xanthii was sequenced and annotated, from which have been identified the epiphytic secretome composed of 138 proteins, including 53 Podosphaera effector candidates (PECs) (Vela-Corcía et al. 2016). In this study, we used the vector Agrobacterium tumefaciens to conduct the HIGS analysis of PEC genes by the agroinfiltration of melon cotyledons. A set of seven $P$. xanthii PEC genes has been analyzed to test their individual participation in disease establishment. Six of them were demonstrated to play a significant role in pathogenesis. The transient knockdown of four of these candidate effector genes resulted in an important reduction of fungal development and activation of plant defense responses. This, together with protein modeling studies and ligand predictions as well as the confirmation of the biochemical activities of three of them allowed us to hypothesize about the particular role of these genes in the plantpathogen interaction. This is the first study that identifies and validates PEC genes in $P$. xanthii.

\section{RESULTS}

\section{Selection and sequence analysis}

of $P$. xanthii PECs and expression analysis.

From the predicted epiphytic secretome previously identified for P. xanthii (Vela-Corcía et al. 2016), seven PECs were selected for gene silencing assays. All of them were characterized by the presence of a signal peptide (SP) and the absence of a transmembrane domain in the mature protein. The chosen candidate effectors shared no sequence homology, belong to different families of paralogs, as identified by Vela-Corcía et al. (2016), and did not show homology with any protein present in melon and other cucurbits. The sequences of PECs used in this study are available in the National Center for Biotechnology Information database under the accession numbers listed in Table 1.

The homology analysis by BLASTx showed that six of these candidate effectors, PEC007, PEC008, PEC009, PEC019, PEC032, and PEC054, have significant sequence similarity with hypothetical proteins from different species of filamentous fungi. The remaining effector candidate, PEC034, has similarity with a putative PPE protein from Erysiphe necator. PPE (derived from characteristic motif Pro-Pro-Glu) proteins are characteristic for Mycobacterium tuberculosis. Its role on mycobacterial virulence is not clearly understood, but emerging works involve PPE proteins in infectious processes at multiple levels (Sampson 2011). Among the nonannotated proteins, PEC054 has a highly conserved cerato-platanin structure and is a small secreted protein related to pathogenesis. Analysis of its amino acid sequence showed the typical characteristics of proteins belonging to the cerato-platanin family, with a protein size of 119 amino acids and four cysteines that may form disulfide bridges. PEC008 presents a high similarity with a hypothetical protein from Blumeria graminis and contains a cupredoxin domain, whereas PEC032 presents homology with B. graminis DUF1237, a protein with a highly conserved DUF (domain of unknown function). Among our set of candidates, PEC032 has the largest size (522 amino acids) and PEC007 is the smallest protein ( 38 amino acids). PEC007 shows homology with a hypothetical protein from Sclerotinia sclerotiorum.

The analysis of expression during the early stages of pathogenesis showed that all PEC genes increased the expression at $24 \mathrm{~h}$ postinoculation (hpi), with their expression declining at 48 (PEC009, PEC019, PEC054) or 72 hpi (PEC008, PEC032, and $P E C 034)$ (Fig. 1). The only exception was PEC007, whose expression remained constant during the timepoints analyzed. Furthermore, the candidates more highly expressed were PECO32 and PEC054, followed by PEC007 and PEC034.

\section{A. tumefaciens is a very efficient system for the transformation of melon cotyledon cells and does not affect $P$. xanthii development.}

In this study, melon cotyledons were used to conduct HIGS analysis of PEC genes. For this purpose, we used A. tumefaciens as a vector for the delivery of silencing constructs into melon cells. Agrobacterium-mediated transformation is usually used in the mature leaves of

Table 1. Features of the Podosphaera xanthii effector candidates (PECs) used in this study

\begin{tabular}{|c|c|c|c|c|c|c|}
\hline PEC $^{\mathbf{a}}$ & Accession no. & Protein $^{\mathbf{b}}$ & Short description (BLASTp) & E-value & Sequence identity & Subject ID \\
\hline PEC007 & KX267933 & 38 & $\begin{array}{l}\text { Hypothetical protein Sclerotinia } \\
\text { sclerotiorum }\end{array}$ & $9 \times 10^{-9}$ & $51 \%(30 / 59)$ & XP_003718968 \\
\hline PEC008 & KX278425 & 277 & $\begin{array}{l}\text { Cupredoxin domain protein Blumeria } \\
\text { graminis f. sp. hordei }\end{array}$ & $1 \times 10^{-54}$ & $65 \%(192 / 295)$ & CCU76906 \\
\hline PEC009 & KX278426 & 108 & $\begin{array}{l}\text { Hypothetical protein Blumeria graminis f. sp. } \\
\text { hordei }\end{array}$ & $2 \times 10^{-22}$ & $52 \%(67 / 129)$ & CCU81662 \\
\hline PEC019 & KX278428 & 175 & Hypothetical protein Sclerotinia borealis & $3 \times 10^{-51}$ & $53 \%(102 / 193)$ & ESZ93123 \\
\hline PEC032 & KX278427 & 522 & DUF1237 domain protein Blumeria graminis & 0.0 & $71 \%(388 / 546)$ & CCU75902 \\
\hline PEC034 & KX267934 & 285 & Putative PPE protein Erysiphe necator & $3 \times 10^{-45}$ & $65 \%(162 / 303)$ & KHJ31197 \\
\hline PEC054 & KX278424 & 119 & $\begin{array}{l}\text { Cerato-platanin domain protein } \\
\text { Phialocephala subalpina }\end{array}$ & $8 \times 10^{-57}$ & $64 \%(86 / 135)$ & CZR50164 \\
\hline
\end{tabular}

\footnotetext{
${ }^{\text {a }}$ Formerly known as candidate secreted effector proteins (CSEPs) (Vela-Corcía et al. 2016).

$\mathrm{b}$ Number of amino acids in mature protein without secretion peptide.
} 
dicotyledonous plants; however, mature melon leaves are extremely thin and agroinfiltration was shown to be very difficult and problematic because of the significant damage inflicted on leaves (data not shown). Thus, we carried out the HIGS assays using melon cotyledons, a plant tissue that is also very susceptible to powdery mildew. As a preparatory step to these assays, the ability of $A$. tumefaciens to transform melon cotyledons was determined. For this purpose, we used the plasmid pGWB6 that carries the $g f p$ reporter gene under the control of the Cauliflower mosaic virus (CaMV) $35 \mathrm{~S}$ promoter and its corresponding empty vector $\mathrm{pGWB} 2$ as a negative control (Fig. 2) (Table 2). After the infiltration of melon cotyledons, large circular areas with a darker color than the rest of the tissue denoted the infiltrated areas. Twenty-four hours after agroinfiltration with pGWB6, intense and homogeneous fluorescence signals were observed in localized areas of the infiltrated zone. Intense fluorescence areas were maintained up to six days after infiltration. Thereafter, fluorescence emission decreased considerably. Melon cotyledons noninfiltrated or infiltrated

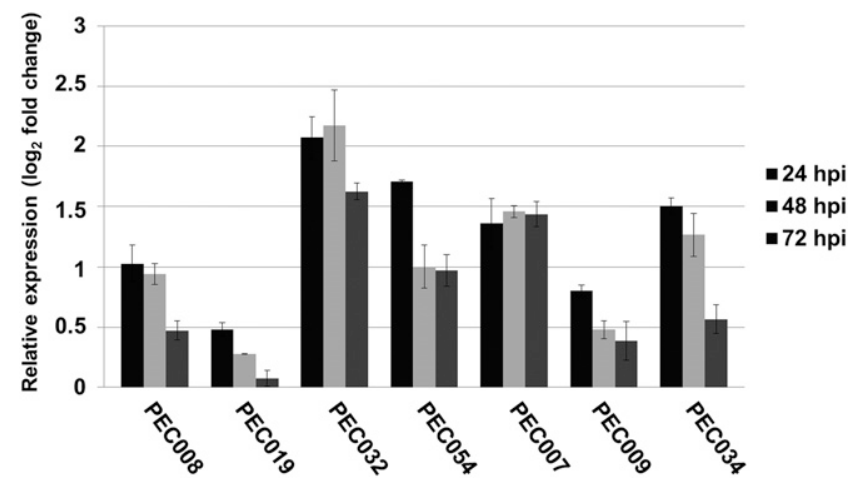

Fig. 1. Analysis of the expression of Podosphaera xanthii effector candidate $(P E C)$ genes during fungal development. Total RNA was isolated from melon cotyledons inoculated with $P$. xanthii at different timepoints $(0,24$, 48, and $72 \mathrm{~h}$ postinoculation [hpi]), and the relative expression of PEC genes was analyzed by quantitative reverse transcription-polymerase chain reaction. Transcript abundance was normalized to the transcription of the endogenous control $\beta$-tubulin gene PxTUB2 (KC333362). Relative expression of each PEC gene was calibrated to 0 hpi. The data shown represents average values of four experimental replicates from three independent experiments, with error bars depicting the standard error. with pGWB2 (empty vector) did not show green fluorescent protein (GFP) fluorescence, and, more importantly, the leaf tissue expressing GFP was also susceptible to $P$. xanthii (Supplementary Fig. S1). These results clearly showed that A. tumefaciens was an efficient system to transform melon cotyledon cells and that pGWB6 could be routinely used to label infiltrated areas for HIGS assays without interfering with fungal growth.

\section{The development of $P$. xanthii is affected by the silencing of $P E C$ genes.}

If a given candidate effector has a relevant contribution to pathogenesis, silencing of the corresponding gene should result in an altered pattern of normal fungal development. Under this premise, we initially tried to analyze the development of the fungus, by calcofluor staining and counting the number of haustoria, as previously shown by Romero et al. (2008). However, melon cotyledon tissue is thicker than leaf tissue, and the expected fluorescent yellow spots corresponding to haustorial penetration sites could not be properly visualized (data not shown). Thus, for haustorial counts, we used the cotyledon discs prepared for histochemical detection of hydrogen peroxide, where haustoria were easily identified as brown dark spots along the hyphae and inside epidermal cells (Fig. 3A). For this analysis, the cotyledon areas examined were those showing GFP fluorescence because, in HIGS assays, silencing constructs (Table 2) were always cotransformed with pGWB6 $(g f p)$ to identify the transformed tissues. Prior to this analysis, however, the expression of silencing constructs was checked as well as the suppression of the expression of the target PEC genes. At $24 \mathrm{hpi}$, the expression of all silencing constructs and the suppression of gene expression of the respective PECs were at similar levels, with reductions of gene expression of about 40 to $50 \%$, in most cases (Supplementary Fig. S2).

The silencing of PECOOS did not affect fungal growth, showing a similar growth pattern as the empty-vector negative control, in which the number of haustoria progressively increased over time (Fig. 3A). The silencing of the other candidate effector genes resulted in a reduction of fungal growth. This negative effect was already observed at $48 \mathrm{hpi}$, becoming evident at 72 hpi (Fig. 3A). The candidate effectors that showed the highest contribution to pathogenesis were PEC009 and PEC034, whose gene silencing drastically reduced the number

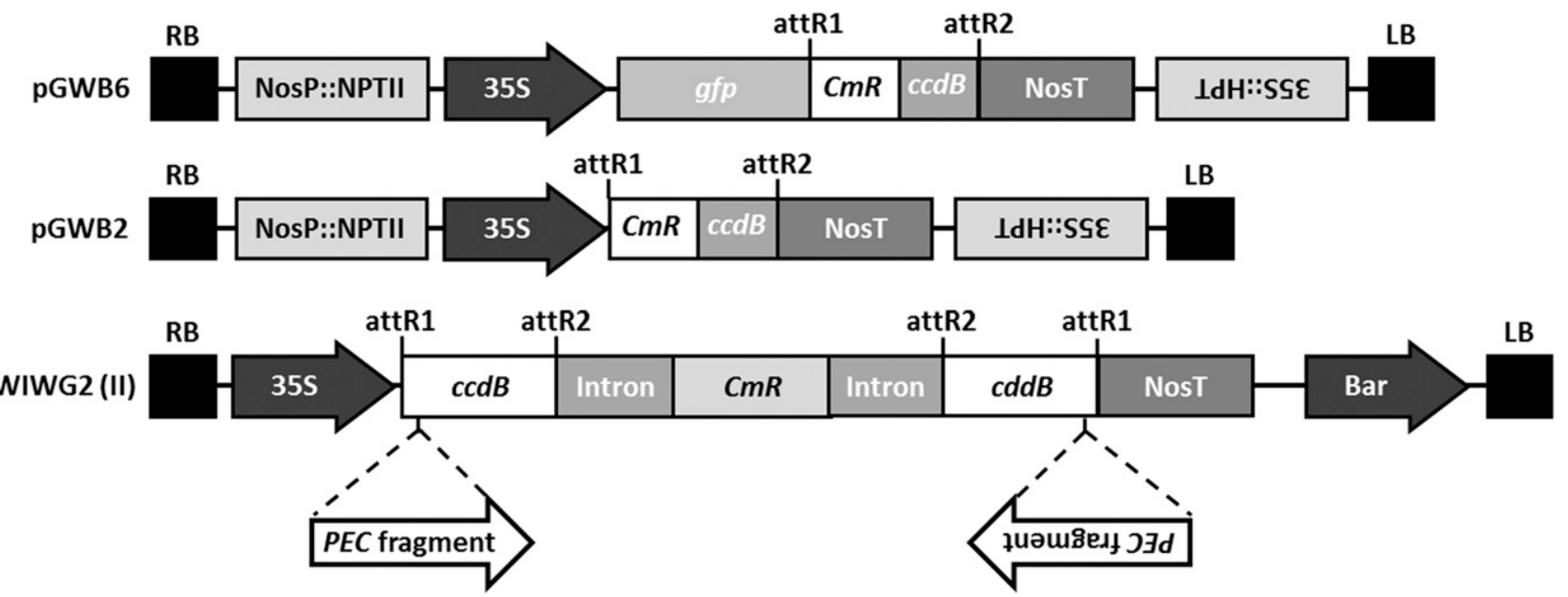

Fig. 2. A schematic representation of T-DNA regions in the vectors used in this study. LB = left border, RB = right border; NosP : NPTII $=$ kanamycin resistance marker, $35 \mathrm{~S}=$ Cauliflower mosaic virus $35 \mathrm{~S}$ promoter,; gfp = green fluorescence protein, $\mathrm{CmR}=$ chloramphenicol resistance marker; ccdB $=$ lethal gene for negative selection in bacteria, NosT = nopaline synthase terminator, 35S::HPT $=$ hygromycin B resistance marker, Bar $=$ glufosinate ammonium resistance marker. For the construction of host-induced gene silencing vectors, the positions of the insertion of the Podosphaera effector candidate (PEC) gene fragments in the destination vector pB7GWIWG2 (II) are indicated. 
of haustoria to similar levels as the CmMlol gene-silencing construct (Cheng et al. 2012) (RNAi-mediated resistance positive control), promoting a sharp reduction in the number of haustoria compared with the empty vector (Fig. 3A). To validate the data obtained from the haustorial count, we carried out the molecular quantification of $P$. xanthii biomass after gene silencing by quantitative polymerase chain reaction (qPCR). For this assay, total DNA was isolated from infected melon cotyledons at 72 hpi. Indeed, the qPCR method corroborated the results obtained by haustorial count, showing that fungal growth was differentially affected by candidate effector gene silencing (Fig. 3B).

The haustorial counts corresponding to 72 hpi were used to calculate the percentages of fungal growth reduction corresponding to the different candidate effector genes (Table 3). Fungal growth reduction data were statistically compared and, according to significant differences, the effects of gene silencing on fungal development were classified in four different categories: no effect, low, intermediate, and high effect. According to this classification, the silencing of PECOO8 had no effect, whereas PECO19 and PECO32 caused low reductions of fungal development. By contrast, the silencing of PEC054 and PECOO7 and especially PECO09 and PEC034 caused intermediate and high reductions of fungal growth, respectively.

\section{Silencing of $P E C$ genes induce different defense responses.}

It is widely accepted that a major role of fungal effectors is related to the manipulation of plant defenses. To analyze the effect of the silencing of candidate effector genes on plant defense responses, the accumulation of hydrogen peroxide in epidermal cells was studied by histochemical detection and was quantified by the counts of reacting cells at different timepoints (Fig. 4; Table 4). This plant defense response was observed as brownish-red precipitates corresponding to $\mathrm{H}_{2} \mathrm{O}_{2}$ accumulation under a light microscope (Fig. 4D, arrow). The silencing of PECO08 did not show a significant increase in the plant response compared with empty vector. By contrast, the silencing of the remaining six effectors triggered defense responses in the plant, with different intensities and at different timepoints (Table 4).

For PECO19 and PEC032, the results obtained after gene silencing were very similar, a slight increase in the accumulation of hydrogen peroxide that progressively increased over time (Table 4). A stronger response was obtained by the silencing of PECOO7 and PECO54. However, in the case of PECOO7, the response was slightly weaker than that of PEC0054, at 24 and $48 \mathrm{hpi}$; at $72 \mathrm{hpi}$, the highest accumulation of reacting cells was found. In general terms, the strongest responses were obtained by the silencing of PECO034 and especially by PECO09. The results of PECO034 were very similar to those obtained by the silencing of $C m M L O 1$ (RNAi-mediated resistance positive control), but the responses of PEC009 were particularly high at 24 and 48 hpi (Table 4).

Interestingly, these responses correlated very well with the fungal growth phenotypes obtained by gene silencing, such that the PEC genes showing the highest defense responses, PECO09 and $P E C 034$, also showed the highest reduction of fungal growth, and vice versa, the PEC genes with the lowest impact on fungal development showed the lowest accumulation of hydrogen peroxide (Table 4). Representative photographs of these different responses are shown in Figure 4. Responses corresponding to silencing of $P E C 008$ with no effect on fungal growth and PEC032, PEC054, and PECO09 as representatives of low, intermediate, and high effect phenotypes on fungal growth, respectively, can be compared with empty vector (negative control) and CmMlol (RNAi-mediated resistance positive control).

\section{Protein modeling and protein-ligand predictions reveal putative functions for some PECs.}

To gain insight into the biological functions of analyzed PECs, protein models were obtained for each, using the I-TASSER server and amino acid sequence of the mature proteins. In addition, a set of prediction tools, CATH/Gene3D, $\mathrm{COACH}, 3 \mathrm{DLigandSite}$, GalaxySite, and Motif scan, was used for function and ligand predictions using both the protein predicted models as amino acid sequence. The PEC007 model presented significant homology with a methionyl-tRNA synthetase (MetRS)

Table 2. Plasmids used in this study

\begin{tabular}{|c|c|c|}
\hline Plasmid & Relevant characteristics ${ }^{\mathbf{a}}$ & Reference \\
\hline pGWB6 & $\begin{array}{l}\text { Plasmid containing } g f p \text { gene under the control of a CaMV } \\
35 \mathrm{~S} \text { promoter }\end{array}$ & Nakagawa et al. 2007 \\
\hline pGWB2 & Empty vector, negative control for HIGS assays & Nakagawa et al. 2007 \\
\hline pPEC007-HIGS & $\begin{array}{l}\text { HIGS vector containing a hairpin RNA with a 177-bp fragment } \\
\text { of } P E C 007\end{array}$ & This study \\
\hline pPEC008-HIGS & $\begin{array}{l}\text { HIGS vector containing a hairpin RNA with a 392-bp fragment } \\
\text { of } P E C 008\end{array}$ & This study \\
\hline pPEC009-HIGS & $\begin{array}{l}\text { HIGS vector containing a hairpin RNA with a } 288 \text {-bp fragment } \\
\text { of } P E C 009\end{array}$ & This study \\
\hline pPEC019-HIGS & $\begin{array}{l}\text { HIGS vector containing a hairpin RNA with a 388-bp fragment } \\
\text { of PEC019 }\end{array}$ & This study \\
\hline pPEC032-HIGS & $\begin{array}{l}\text { HIGS vector containing a hairpin RNA with a 365-bp fragment } \\
\text { of } P E C 032\end{array}$ & This study \\
\hline pPEC034-HIGS & $\begin{array}{l}\text { HIGS vector containing a hairpin RNA with a 391-bp fragment } \\
\text { of } P E C 034\end{array}$ & This study \\
\hline pPEC054-HIGS & $\begin{array}{l}\text { HIGS vector containing a hairpin RNA with a 373-bp fragment } \\
\text { of } P E C 054\end{array}$ & This study \\
\hline pCmMlo1-RNAi & $\begin{array}{l}\text { RNAi vector containing a hairpin RNA with a 412-bp fragment } \\
\text { of CmMlo1, positive control for HIGS assays }\end{array}$ & This study \\
\hline pPEC019-EXPR & $\begin{array}{l}\text { Expression vector carrying the coding region of } P E C O 19 \text { without } \\
\text { SP fused to 6-His tag at N-terminal end }\end{array}$ & This study \\
\hline pPEC032-EXPR & $\begin{array}{l}\text { Expression vector carrying the coding region of } P E C O 32 \text { without } \\
\text { SP fused to 6-His tag at N-terminal end }\end{array}$ & This study \\
\hline pPEC054-EXPR & $\begin{array}{l}\text { Expression vector carrying the coding region of PECO54 without } \\
\text { SP fused to 6-His tag at N-terminal end }\end{array}$ & This study \\
\hline
\end{tabular}

\footnotetext{
${ }^{\mathrm{a}} \mathrm{CaMV}=$ Cauliflower mosaic virus, $\mathrm{HIGS}=$ host-induced gene silencing, $\mathrm{RNAi}=\mathrm{RNA}$ interference, and $\mathrm{SP}=$ secretory signal peptide.
} 
from Pyrococcus abyssi (1RQG) according to I-TASSER. On the other hand, the PEC007 model and sequence showed interaction with putative ligands such as peptides, adenine, and $S$ adenosylmethionine and putative activity as a methyltransferase (Table 5; Fig. 5A). Taken together, a putative function of PEC007 could be the methylation of plant DNA or proteins.

The resulting model of the PEC008 amino acid sequence showed no homology with any eukaryotic protein. On the other hand, Phyre 2 predictions showed high homology with a stellacyanin (1JER) and a cupredoxin from cucumber (Cucumis sativus) with electron transfer properties. Ligand prediction indicated putative interactions with copper ions (Table 5; Fig. 5B). These predictions suggest that PEC008 could be a secreted protein involved in electron transfer.

The PEC009 protein model showed homology with paraspeckleprotein heterodimer PSPC1/NONO (3SDE), a human RNA binding protein. Ligand prediction suggests that PEC009 could interact with nucleic acids, phosphate, and peptides (Table 5; Fig. 5C). According to these predictions, PEC009 could act as a regulator of plant gene expression.

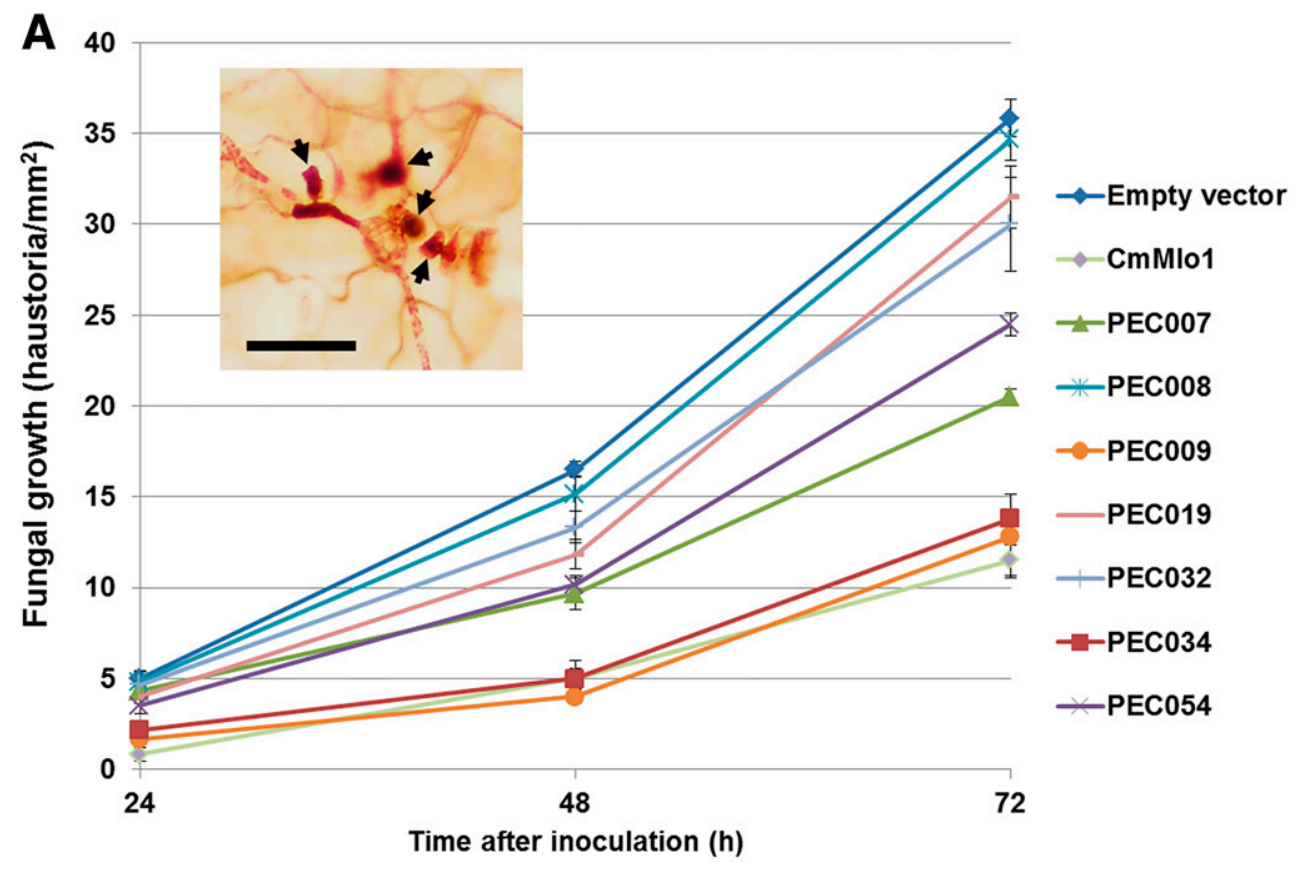

B

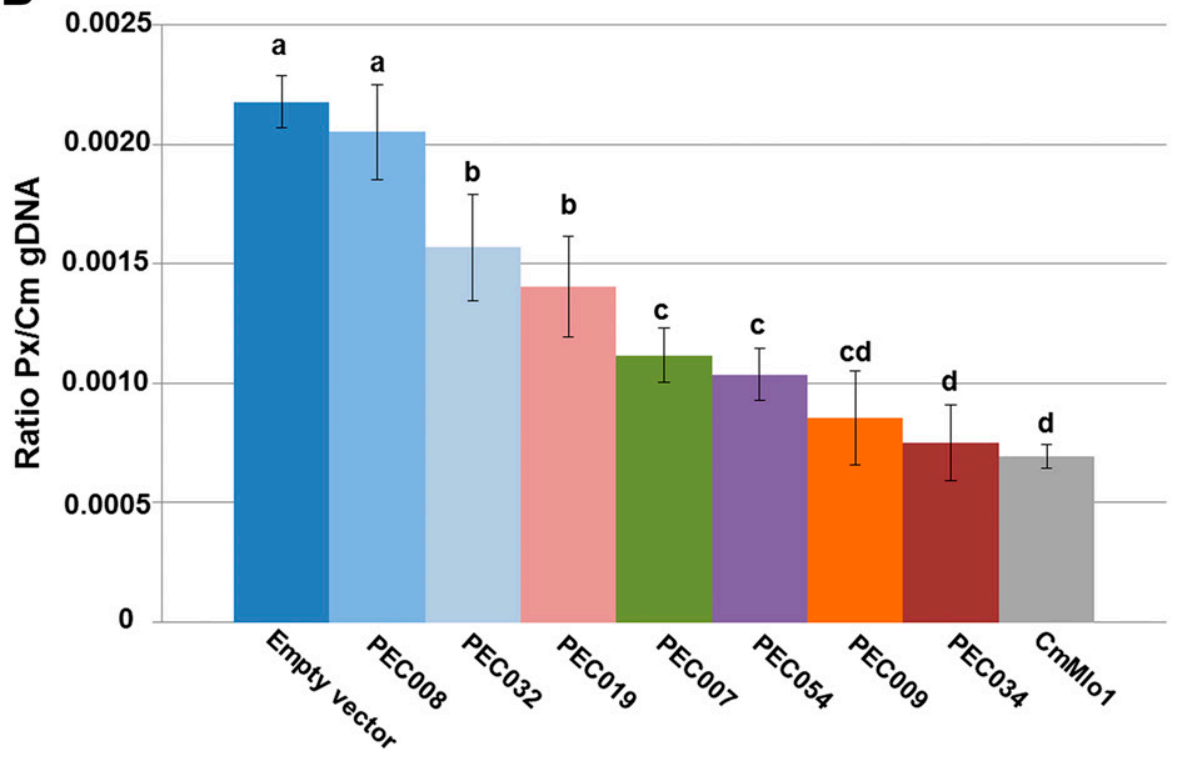

Fig. 3. Analysis of the effect of host-induced gene silencing (HIGS) mediation of Podosphaera xanthii effector candidate (PEC) genes on the fungal growth. A, Effect of HIGS-mediated silencing of $P E C$ genes on the formation of $P$. xanthii haustoria. RNA interference (RNAi) silencing was performed using Agrobacterium tumefaciens-mediated HIGS, and the haustorial count was carried out in the discs prepared for $\mathrm{H}_{2} \mathrm{O}_{2}$ detection, showing haustoria easily identified as brown dark spots (arrows in the photograph). As a negative control, the same vector used for RNAi silencing was employed without insert (empty vector). As a positive control for RNAi-induced resistance, RNAi silencing of the melon CmMlo1 gene was used. Fungal growth is expressed as the number of haustoria per square millimeter of transformed tissue. Values represent the mean value of 60 sample discs from three independent experiments. Bars represent the standard error. Scale bar $=50 \mu \mathrm{m}$. B, Quantitative polymerase chain reaction (qPCR) analysis of $P$. xanthii growth on melon cotyledon after agroinfiltration. Samples were taken at $72 \mathrm{~h}$ postinoculation. Ratios of $P$. xanthii to melon cotyledon (Cucumis melo) genomic DNA were determined by qPCR. Bars represent the mean \pm standard error of three DNA samples (each derived from five pooled cotyledons) with three technical replicates each. Data points followed by the same letter are not significantly different at $P=0.05$ according to least significant difference test. 
The PEC019 model showed high homology with the crystal structure of a soluble chemoreceptor from Thermotoga maritime (2CH7) and showed high homology with F-BAR domains of human (4DYL) and yeast (4WPE) (Table 5; Fig. 5D). F-BAR domains control membrane interactions in endocytosis, cytokinesis, and cell signaling. Interestingly, ligand prediction suggests the putative interaction of PEC019 with a membrane lipid, palmitoyl-linoleoyl phosphocholine (Table 5). These results suggest that PEC019 could be a lipid-binding protein involved in the modulation of plant cell membrane organization.

The PEC032 model showed high homology with the crystal structures of three exo- $\alpha-1,6$-mannosidases from Bacteroides ovatus (3P2C), Streptococcus pneumoniae (3QPF), and Clostridium perfringens (3QT3) (Fig. 5E; Table 5). The prediction identified PEC032 as a six-hairpin glycosidase with exo- $\alpha-1,6-$ mannosidase activity. Furthermore, $\alpha$-mannose and $\beta$-mannose were predicted as the most likely ligands (Table 5). Upon alignment using the sequence of the templates, the crystal structures showed that conserved regions between $\alpha$-mannosidases are present in PEC032 (Supplementary Fig. S3), also identifying catalytic residues (Gregg et al. 2011).

The model of PEC054 showed high homology with the crystal structure of Sm1 protein from Trichoderma virens (3M3G), an elicitor of plant defense responses (Table 5; Fig. 5F). Ligand predictions revealed that PEC054 could interact with polysaccharides such as cellopentaose (a cellulose degradation product) and xylopyranose (a hemicellulose derivative) (Table 5). The alignment conducted using the available sequence from a $B$. graminis homolog and other crystallized cerato-platanin proteins from different fungi showed the conserved amino acids of cerato-platanin proteins (Yap et al. 2015), including the four cysteines (Supplementary Fig. S4).

The PEC034 model obtained a high homology with yeast Brol (4JIO) and human ALIX (2R02) proteins. Computational predictions indicate that PEC034 could act as an ALIX-like protein, interacting with peptides and ATP/GTP (Table 5; Fig. 5G). Moreover, motif scan prediction indicates the presence of ATP/GTP-binding site and N-myristoylation motifs and a glycine-rich region, all typical features of ALIX proteins, suggesting that PEC034 could mimic a host ALIX protein and interfere with the vesicle trafficking of host plant cells. Accordingly, the PEC034 model showed a great similarity with the melon ALIX protein model (Fig. 5G).

\section{Biochemical activities of $P$. xanthii PECs.}

Based on computational predictions, the biochemical activities of PEC019, PEC032, and PEC054 were tested using proteins expressed in vitro in Escherichia coli (Supplementary Fig. S5). In the case of PEC019, despite having no obvious lipid-binding domain, computational predictions indicated interaction with lipids. Therefore, we performed a lipid-binding assay conducted using prespotted PIP strips to test whether PEC019 binds to phospholipids (Fig. 6). We found that PEC019 specifically bound to several phospholipids. His-tagged PEC019 showed a strong binding activity for lysophosphatidic acid, phosphatidylinositol 4-phosphate, and phosphatidic acid and a weaker binding ability for phosphatidylinositol 3phosphate and phosphatidylinositol 5-phosphate. By contrast, no binding signals were detected when the His-tagged PEC032 and PEC054 were used. Based on its biochemical activity, PEC019 was renamed PxPLBE1 ( $P$. xanthii phospholipidbinding effector 1$)$.

The predicted $\alpha$-mannosidase activity of PEC032 was tested against synthetic substrate 4-nitrophenyl- $\alpha$-D-mannopyranoside, using PEC019 and PEC054 as negative controls (Fig. 7). We confirmed the $\alpha$-mannosidase activity of His-tagged
PEC032 by the release of 4-nitrophenol from the synthetic substrate, as shown by the increase in absorbance in the presence of different concentrations of PEC032 (Fig. 7A). As recommended by the manufacturer, at $10 \mathrm{~min}$ of incubation, the PEC032 protein released little 4-nitrophenol. However, when longer incubation times were tested, a maximum $\alpha$-mannosidase activity for PEC032 was found at $45 \mathrm{~min}$ of incubation. By contrast, only residual activity could be attributed to PEC019 and PEC054 (Fig. 7B). Based on its biochemical activity, PEC032 was renamed PxMLE1 (P. xanthii $\alpha$-mannosidase-like effector 1 ).

In the case of PEC054, prediction tools identified cellopentaose as a putative ligand molecule. However, since other cerato-platanins have been described to bind chitin (Baccelli 2015), we first conducted a carbohydrate-binding assay using insoluble substrates such as chitin, cellulose, and xylan and bovine serum albumin as a negative control. After incubation of His-tagged PEC054 with the different substrates, there was a large decrease of soluble protein only in the presence of cellulose, indicating that PEC054 has only affinity for cellulose (Supplementary Fig. S6). After determining the ability of PEC054 to bind cellulose, we tested its potential to sequester cellulose fragments (cellopentaose) and prevent the activation of cellulose-triggered immunity (Fig. 8), since cellulose derivatives from plant cell-wall degradation also trigger plant responses (Souza et al. 2017; Vallarino and Osorio 2012). In the absence of PEC054, cellopentaose triggered the accumulation of $\mathrm{H}_{2} \mathrm{O}_{2}$ in epidermal cells $24 \mathrm{~h}$ after the infiltration of melon leaves; however, the coinfiltration of His-tagged PEC054 and cellopentaose decreased notably the number of plant cells accumulating $\mathrm{H}_{2} \mathrm{O}_{2}$. By contrast, coinfiltration of His-tagged PEC019 and PEC032 had no effect on the plant response (Fig. $8 \mathrm{~A})$. To confirm these results, we tested cellulose-binding activity, using different concentrations of cellopentaose and different concentrations of His-tagged PEC054. As shown in Figure $8 \mathrm{~B}$, the suppression of cellulose-triggered immunity was reduced as the PEC054 concentration increased. As expected, His-tagged PEC019 and PEC032 had no effect on cellulosetriggered elicitation (Fig. $8 \mathrm{~B}$ ). These results suggest that PEC054 suppressed the process of cellulose recognition by the plant. Based on its biochemical activity, PEC054 was renamed PXCLBE1 (P. xanthii cellulose-binding effector 1).

Table 3. Effect of silencing of Podosphaera xanthii effector candidate $(P E C)$ genes on fungal development ${ }^{\mathrm{a}}$

\begin{tabular}{|c|c|c|c|}
\hline \multirow[b]{2}{*}{ PEC } & \multirow[b]{2}{*}{ No. of haustoria ${ }^{b}$} & \multicolumn{2}{|c|}{ Fungal growth } \\
\hline & & Reduction $(\%)^{\mathrm{c}}$ & Phenotype $^{d}$ \\
\hline Empty vector & $35.83 \pm 1.04 \mathrm{a}$ & - & - \\
\hline PEC008 & $34.66 \pm 1.14 \mathrm{a}$ & 3.26 & No effect \\
\hline PEC019 & $31.5 \pm 1.72 b$ & 12.08 & Low \\
\hline PEC032 & $30 \pm 2.58 b$ & 16.27 & Low \\
\hline PEC054 & $24.5 \pm 0.62 \mathrm{c}$ & 31.62 & Intermediate \\
\hline PEC007 & $20.5 \pm 0.43 \mathrm{~d}$ & 42.78 & Intermediate \\
\hline PEC034 & $13.85 \pm 1.30 \mathrm{e}$ & 61.34 & High \\
\hline PEC009 & $12.83 \pm 2.28 \mathrm{e}$ & 64.19 & High \\
\hline CmMlo1 & $11.5 \pm 0.92 \mathrm{e}$ & 67.9 & High \\
\hline
\end{tabular}

a Fungal growth, expressed as number of haustoria per square millimeter, was recorded $72 \mathrm{~h}$ after inoculation.

b Data represent the average number of haustoria from 60 samples from three independent experiments \pm standard error. Values followed by the same letter are not significantly different at $P=0.05$, according to Fisher's least significant difference test.

${ }^{c}$ Percentage of fungal growth reduction achieved by the gene silencing of each PEC referenced to values of haustorial count in empty vector (negative control).

${ }^{d}$ Phenotype describing the impact on fungal growth of the gene silencing of each $P E C$ according to statistical differences. 


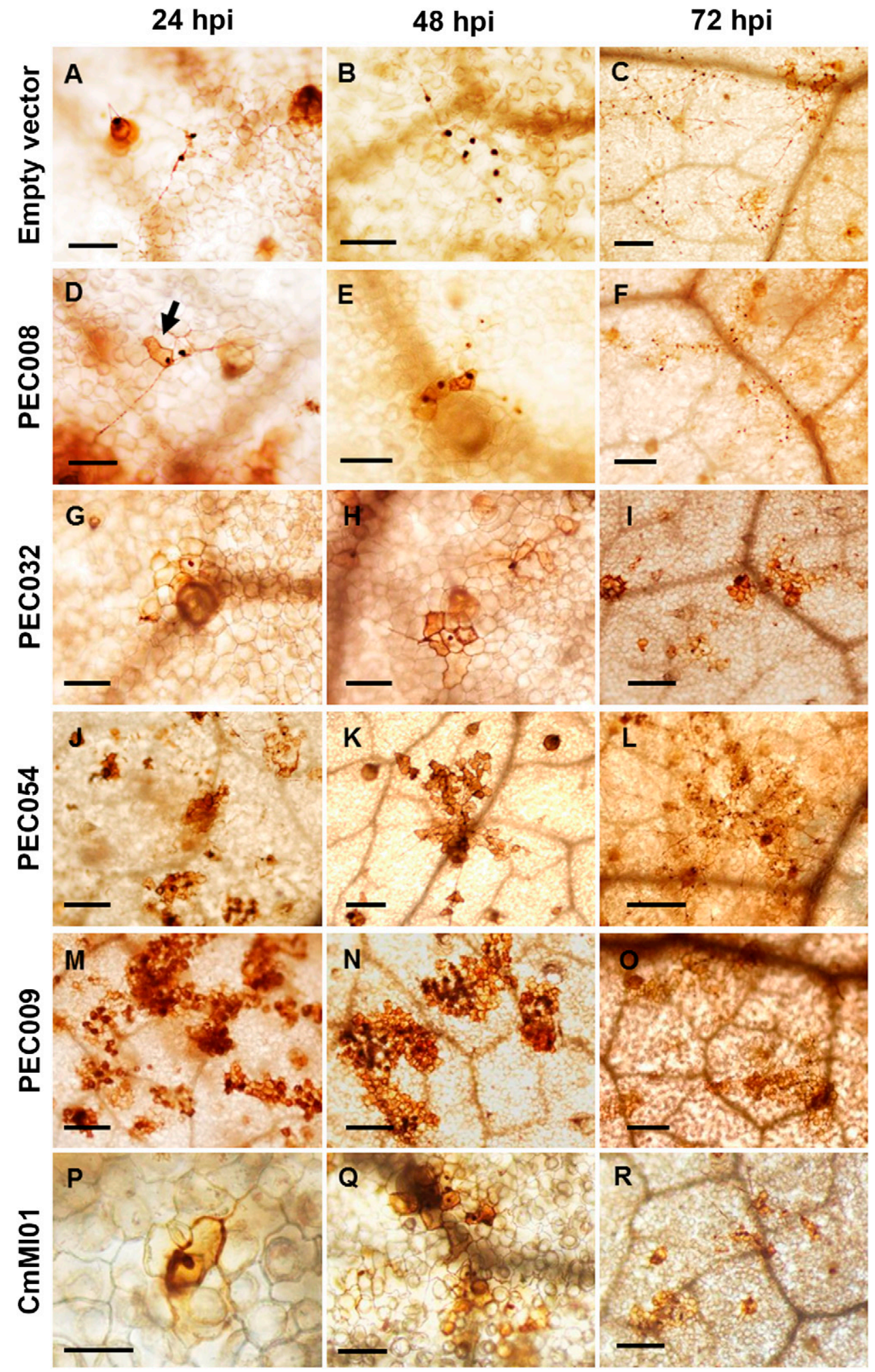

Fig. 4. Effect of host-induced gene silencing (HIGS) mediation of Podosphaera xanthii effector candidate (PEC) genes on the production of hydrogen peroxide

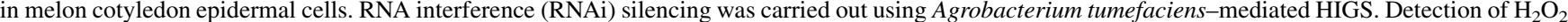
was performed by the 3,3'-diaminobenzidine-uptake method. Photographs were taken at 24,48 , and $72 \mathrm{~h}$ after the inoculation of $P$. xanthii. A to C, Empty vector negative controls. D to $\mathbf{F}$, Effect on $\mathrm{H}_{2} \mathrm{O}_{2}$ accumulation of the RNAi silencing of PEC008, as a representative of the no-effect phenotype on fungal growth, $\mathbf{G}$ to $\mathbf{I}, P E C 032$ as a representative of the low-effect phenotype, $\mathbf{J}$ to $\mathbf{L}, P E C 054$ as a representative of the intermediate-effect phenotype, and $\mathbf{M}$ to $\mathbf{O}$, PEC009 as a representative of the high-effect phenotype. $\mathbf{P}$ to $\mathbf{R}$, Effect on $\mathrm{H}_{2} \mathrm{O}_{2}$ accumulation of RNAi silencing of the melon CmMlo1 gene (positive control for RNAi-induced resistance). The arrow denotes the accumulation of $\mathrm{H}_{2} \mathrm{O}_{2}$ by an epidermal cell. Scale bars $=100 \mu \mathrm{m}(\mathrm{A}, \mathrm{B}, \mathrm{D}, \mathrm{E}, \mathrm{G}, \mathrm{H}, \mathrm{P}, \mathrm{Q}), 200 \mu \mathrm{m}(\mathrm{C}, \mathrm{F}, \mathrm{I}$, $\mathrm{J}, \mathrm{K}, \mathrm{L}, \mathrm{M}, \mathrm{N}, \mathrm{O}, \mathrm{R})$ and $50 \mu \mathrm{m}(\mathrm{P})$. 


\section{Distribution of PLBE1, MLE1, and CLBE1 orthologs in fungi.}

To determine the presence of orthologs for PxPLBE1, PxMLE1, and PxCLBE1 in the genomes of other fungi, DELTA-BLAST searches were carried out using the deduced amino acid sequences of PxPLBE1, PxMLE1, and PXCLBE1 as query sequences. As shown in Table 6, these genes are widely present in fungi, with some exceptions. It is interesting to note that $P L B E$ orthologs are specific for phytopathogenic fungi and saprophytes, which can occasionally be parasites of plants, being absent in mammalian and insect pathogens. Regarding $M L E 1$ orthologs, they are widely present in Ascomycota and absent in some Basidiomycetes species. Finally, CLBE1 orthologs are also widely distributed in Ascomycetes, with a few exceptions, and are absent in yeasts as well as pathogenic Basidiomycetes.

\section{DISCUSSION}

One of the largest problems when studying powdery mildewplant interactions is the lack of knowledge about their molecular biology. To date, there are few annotated effectors from powdery mildews, further complicating their identification and the annotation of de novo transcriptomes and draft genomes. Adding to these difficulties is the peculiar lifestyle of these pathogens, making their genetic manipulation very challenging (Martínez-Cruz et al. 2017). In fact, due to the need of these pathogens to grow on living material, fungal growth and pathogenesis cannot be distinguished, making the selection of mutants defective in virulence genes a very difficult, if not impossible, task (Nowara et al. 2010). To overcome these difficulties, RNAi silencing has emerged as a new approach to analyze the role that individual PEC genes might play in the interaction. In particular, the so-called HIGS system has become very popular. This method has proven to be a very useful tool for the analysis of Blumeria graminis $\mathrm{f}$. sp. hordei candidate effector genes (Ahmed et al. 2015, 2016; Nowara et al. 2010; Pennington et al. 2016; Pliego et al. 2013; Zhang et al. 2012).

Considering the limitation of biolistics to analyze PEC genes, we developed a HIGS method using agroinfiltration to transform melon cotyledon cells (Lacroix and Citovsky 2016). The method was proven to be very effective; the agroinfiltrated areas were transformed with a high efficacy and silencing constructs were similarly expressed, achieving expression reductions of target genes of about 50\%. Additionally, regarding gene silencing control constructs, as expected, empty vectors had no effect on fungal development, whereas the RNAi silencing of the melon Mlol gene resulted in RNAi-induced resistance. We called this method A. tumefaciens-mediated (ATM)-HIGS.

The silencing of seven $P$. xanthii PEC genes by ATM-HIGS resulted in different phenotypes regarding the impact on fungal development and activation of plant defense responses. These phenotypes were classified as null, low, intermediate, or high effect. It is interesting to note that the PEC genes PECO19 and PEC054 showed the lowest impact in HIGS experiments. These low silencing phenotypes could be attributed to the presence of paralogs, as previously observed in the $P$. xanthii epiphytic

Table 4. Time course analysis of accumulation hydrogen peroxide in melon cotyledons in response to inoculation with Podosphaera xanthii after silencing of Podosphaera effector candidate (PEC) genes ${ }^{\mathrm{a}}$

\begin{tabular}{|c|c|c|c|c|}
\hline \multirow[b]{2}{*}{ PEC } & \multirow[b]{2}{*}{ Fungal growth phenotype } & \multicolumn{3}{|c|}{ Time after inoculation } \\
\hline & & $24 \mathrm{~h}$ & $48 \mathrm{~h}$ & $72 \mathrm{~h}$ \\
\hline Empty vector & No effect & $0.17 \pm 0.16 \mathrm{a}$ & $5.00 \pm 0.73 \mathrm{a}$ & $43.67 \pm 1.82 \mathrm{a}$ \\
\hline PEC008 & No effect & $0.34 \pm 0.21 \mathrm{a}$ & $5.50 \pm 0.76 \mathrm{a}$ & $42.17 \pm 2.55 \mathrm{a}$ \\
\hline PEC019 & Low & $4.67 \pm 0.80 \mathrm{ab}$ & $8.33 \pm 0.42 \mathrm{ab}$ & $61.50 \pm 3.78 b$ \\
\hline PEC032 & Low & $6.17 \pm 0.87 \mathrm{ab}$ & $12.33 \pm 1.14 \mathrm{ab}$ & $67.83 \pm 1.13 b c$ \\
\hline PEC054 & Intermediate & $23.83 \pm 1.25 \mathrm{c}$ & $33.67 \pm 1.83 \mathrm{c}$ & $81.50 \pm 9.62 \mathrm{c}$ \\
\hline PEC007 & Intermediate & $12.83 \pm 1.01 \mathrm{~b}$ & $28.33 \pm 3.17 \mathrm{c}$ & $115.67 \pm 13.59 \mathrm{~d}$ \\
\hline PEC009 & High & $101.83 \pm 9.12 \mathrm{~d}$ & $125.50 \pm 7.55 \mathrm{e}$ & $82.67 \pm 1.11 \mathrm{c}$ \\
\hline PEC034 & High & $20.83 \pm 2.30 \mathrm{bc}$ & $48.33 \pm 2.47 \mathrm{~d}$ & $57.83 \pm 1.30 \mathrm{ab}$ \\
\hline CmMlo1 & High & $24.33 \pm 1.90 \mathrm{c}$ & $55.67 \pm 3.87 \mathrm{~d}$ & $59.83 \pm 2.84 \mathrm{ab}$ \\
\hline
\end{tabular}

${ }^{a}$ Data represent the number of reacting cells per square millimeter and are the means of 60 samples from three independent experiments \pm standard error.

Values followed by the same letter are not significantly different at $P=0.05$, according to least significant difference test.

Table 5. Summary of data and predicted features of three-dimensional models of Podosphaera xanthii effector candidates (PECs)

\begin{tabular}{|c|c|c|c|c|c|c|c|}
\hline \multirow[b]{2}{*}{ Protein model } & \multicolumn{2}{|c|}{ Score values ${ }^{\mathbf{a}}$} & \multicolumn{2}{|c|}{ Structural analogs ${ }^{\mathbf{b}}$} & \multicolumn{2}{|c|}{ Predicted features $^{c}$} & \multirow[b]{2}{*}{ Putative target function ${ }^{\mathrm{d}}$} \\
\hline & TM score & C score & PDB file & Species & Activity & Ligands & \\
\hline PEC007 & $0.43 \pm 0.14$ & -2.45 & 1RQG & Pyrococcus abyssi & Methyltransferase & Proteins/nucleic acids & Methylation \\
\hline PEC008 & $0.40 \pm 0.14$ & -2.72 & $1 \mathrm{JER}$ & Cucumis sativus & Oxidoreductase & Copper & - \\
\hline PEC009 & $0.27 \pm 0.08$ & -4.16 & $3 \mathrm{SDE}$ & Homo sapiens & $\begin{array}{l}\text { Transcriptional } \\
\text { regulator }\end{array}$ & Nucleic acids & $\begin{array}{l}\text { Regulation of gene } \\
\text { expression }\end{array}$ \\
\hline PEC019 & $0.44 \pm 0.14$ & -2.38 & $2 \mathrm{CH} 7$ & Thermotoga maritime & $\mathrm{Nd}$ & Membrane lipids & Membrane organization \\
\hline PEC032 & $0.68 \pm 0.12$ & -0.24 & 3QSP & $\begin{array}{l}\text { Streptococcus } \\
\text { pneumoniae }\end{array}$ & Glycoside hydrolase & Mannose & Glycosylation \\
\hline PEC034 & $0.42 \pm 0.14$ & -2.5 & $4 \mathrm{JIO}$ & $\begin{array}{l}\text { Saccharomyces } \\
\text { cerevisae }\end{array}$ & Ubiquitin & Peptides & Vesicle trafficking \\
\hline PEC054 & $0.94 \pm 0.05$ & 1.64 & $3 \mathrm{M} 3 \mathrm{G}$ & Trichoderma virens & $\begin{array}{l}\text { Cellulose binding } \\
\text { protein }\end{array}$ & $\begin{array}{l}\text { Cellopentaose, } \\
\text { xylopyranose }\end{array}$ & DAMP-triggered immunity \\
\hline
\end{tabular}

\footnotetext{
${ }^{a}$ Score values represent the reliability of each model according to I-TASSER. TM scores $>0.5$ indicate a model of correct topology and $<0.17$ mean a random similarity. A confidence (C) score is in the range of -5 to 2 , where a higher value means a model with a higher confidence.

b Protein structurally close to the PEC model according to I-TASSER prediction. PDB = Protein Data Bank.

c Summary of results obtained from software tools CATH, COACH, GalaxySite and Motif Scan. Nd = not determined.

${ }^{\mathrm{d}}$ Interpretation of the results obtained from the protein model and the predicted features. DAMP $=$ damage-associated molecular pattern.
} 
secretome (Vela-Corcía et al. 2016), and therefore, there is a possibility that those paralogs might act redundantly. Alternatively, these phenotypes could be simply due to these higherexpressed PECs still having a sufficient amount of protein despite silencing (Hong et al. 2014). Only the silencing of PECO08 showed a null effect indistinguishable from the negative control; the plant did not show enhanced production of hydrogen peroxide and fungal growth was not compromised. The explanation might lie in the putative function of this protein as an electron transporter. Similar proteins have been previously identified in the transcriptome of other obligate biotrophs, such as Puccinia striiformis f. sp. tritici (Garnica et al. 2013); however, there is no evidence concerning the role of these proteins in pathogenesis. Although PEC008 possesses a secretion SP, it does not necessarily mean that it is secreted into the host; for example, it may play a role as an electron transporter in the extrahaustorial matrix, which contains proteins, among other compounds (Vidhyasekaran 1997).

Among the PEC genes analyzed, the candidates with the lowest but significant contribution to pathogenesis were PECO19 and PEC032. It is widely accepted that the role of fungal effectors is not only to suppress plant defense responses but also to
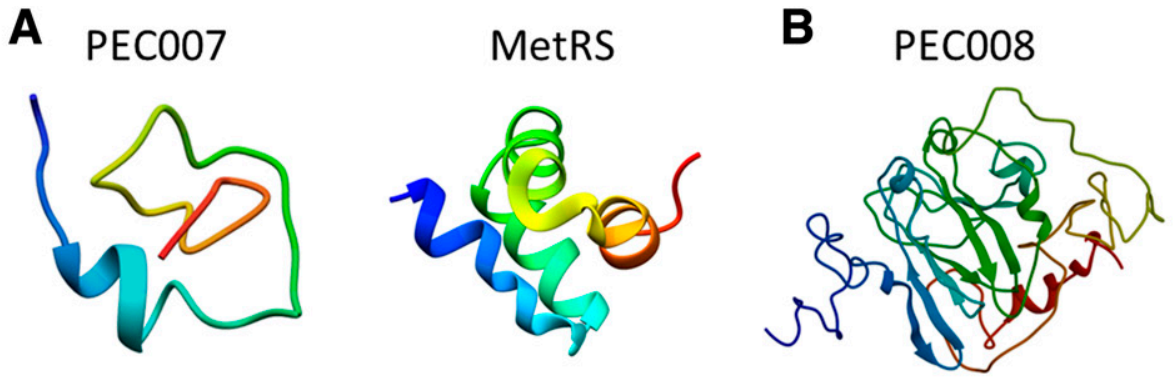

\section{Cupredoxin}
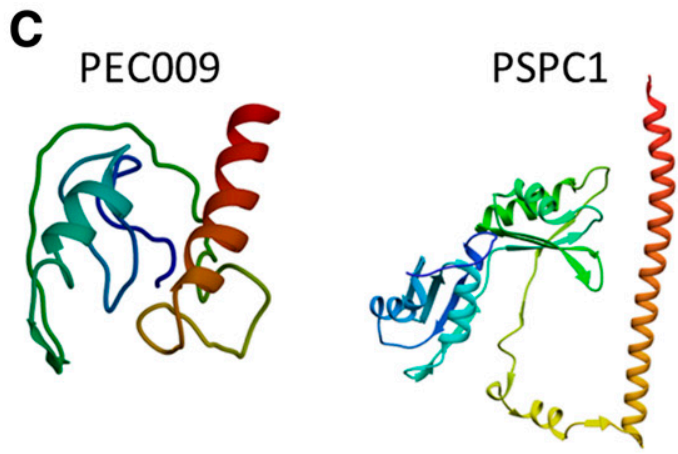

D
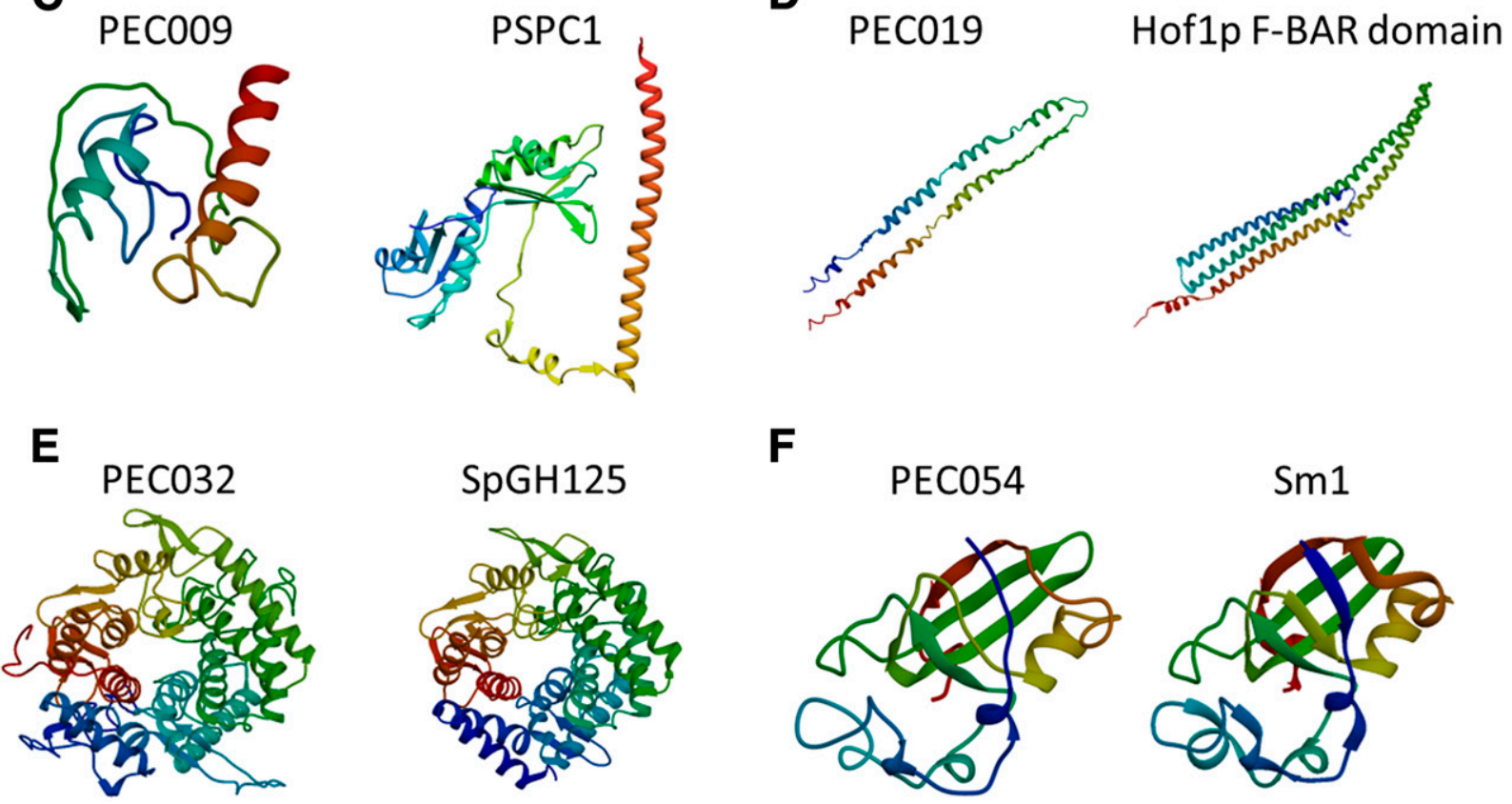

$\mathbf{F}$
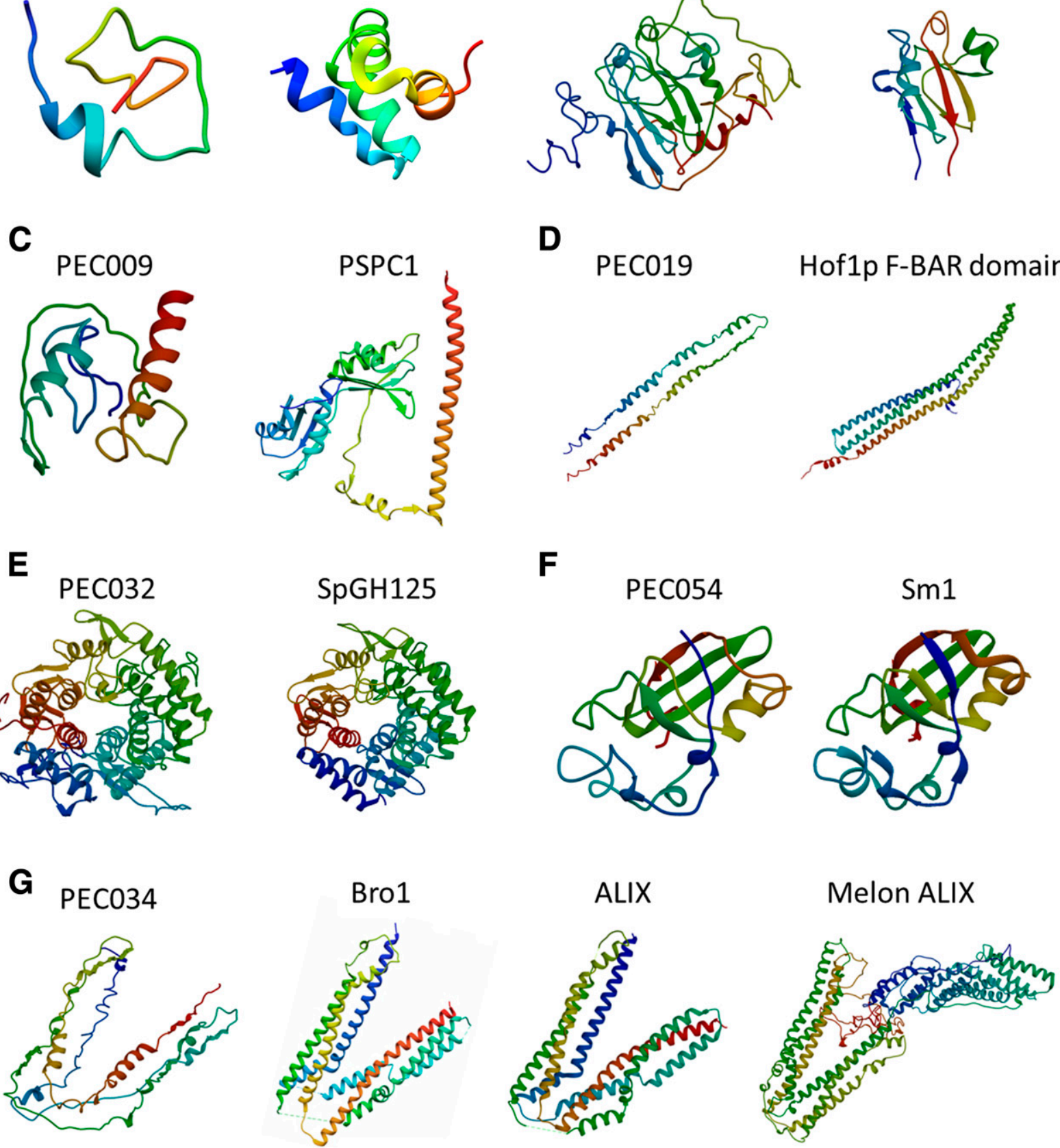

Fig. 5. Predicted three-dimensional (3D) models of Podosphaera xanthii effector candidate $(P E C)$ genes and their best structural analogs. 3D models were constructed using the I-TASSER server. A, PEC007 and a methionyl-tRNA synthetase from Pyroccus abyssi (1RQG). B, PEC008 and a cupredoxin from Cucumis sativus (1JER). C, PEC009 and the human PSPC1 (3SDE). D, PEC019 and the Hof1p F-BAR domain from yeast (4WPE). E, PEC032 and the $\alpha$-mannosidase SpGH25 from Streptococcus pneumoniae (3QSP). F, PEC054 and the cerato-platanin Sm1 from Trichoderma virens (3M3G). G, P. xanthii PEC034 and the yeast ALIX homolog Bro1 (4JIO) and the human ALIX protein (2R02); the melon ALIX protein (XP_008467160) is also shown. 
modulate the physiology and architecture of the host cell to accommodate the invasive structure (Lo Presti et al. 2015). In this context, the PEC019 protein model showed high structural homology with F-BAR domains present in human and yeast proteins, which are related to remodeling cellular membranes, organelle biogenesis, membrane trafficking, cell morphology, and various actin-based processes (Ahmed et al. 2010). The lipid-binding assay showed that His-tagged PEC019 had an affinity for different phospholipids, corroborating the result obtained from computational analysis and allowing us to rename the protein PxPLBE1 (phospholipid-binding effector 1). The lipid-binding assay not only demonstrates that PxPLBE1 has affinity for phospholipids but also suggests the possible roles that this protein might be playing according to the type of phospholipids to which it binds. As observed, PxPLBE1 can interact with lysophosphatidic acid, phosphatidylinositol 3-phosphate [PtdIns(3)P], PtdIns(4)P, PtdIns(5)P, and phosphatidic acid. These results are very interesting from the point of view of a pathogen because these lipids are related with multiple processes in hosts, such as plasma membrane and cytoskeleton modulation, protein recruitment, autophagy, signaling, endocytosis, secretion of vesicles, and regulation of Golgi apparatus, among other functions (D'Angelo et al. 2008; Gillooly et al. 2001; Okudaira et al. 2010; Viaud et al. 2014). Interestingly, the PtdIns(3)P has been described to occur in high presence and act as a signaling molecule in lipid rafts, microdomains enriched in cholesterol, sphingolipids, and phospholipids that are related with abiotic and biotic stress (Grennan 2007). Some pathogens secrete effectors that interact with PtdIns(3)P to regulate vesicular trafficking or to invade host cells and introduce effectors into host cytoplasm via endocytosis (Kale et al. 2010).

This type of activity makes sense in the case of the establishment of haustoria and, therefore, the development of powdery mildew infection. Powdery mildews and other biotrophs have the ability to modify and remodel the structure of plant cells to accommodate inside (Underwood and Somerville 2008). As such, in barley, previous studies have addressed the ability of $B$. graminis f. sp. hordei to directly or indirectly modulate the cytoskeleton of the plant to create a structure as a 'scaffold' for haustoria (Opalski et al. 2005). Further, powdery mildew has shown the ability to modify the plant membrane to form the extrahaustorial membrane, whose protein and lipid composition significantly differ from the plant plasma membrane (Bozkurt et al. 2014; Kim et al. 2014). Further, it has been suggested that pathogens manipulate the lipid composition of host membrane to establish a perimicrobial domain that may enable transfer of molecules, nutrients, and effectors through the pathogen membrane and the host membrane (Bozkurt et al. 2014). In the case of pathogenic bacteria, the manipulation of host plasma membrane by effectors is important for survival in the host and pathogenesis, causing several effects, among which are the suppression of the host response, cytoskeleton alteration, and destabilization of membrane-associated pathways such as vesicle trafficking (Asrat et al. 2014; Ham et al. 2011). Although the silencing phenotype of PECO19 was not very strong, it is tempting to speculate about the role of this type of protein that can interact with membrane lipids and could modify the formation of the plasma membrane. This would represent a new activity for powdery mildew effectors that, interestingly, seems to be widely conserved in fungal plant pathogens and saprophytes that occasionally infect plants. The precise contribution of PLBE1 proteins to the fungal pathogenicity of plants remains to be elucidated.

Regarding PEC032, its structure and ligand prediction data indicate a potential activity as an exo- $\alpha$-mannosidase, an enzymatic activity involved in processing mannose from $\mathrm{N}$ glycans (Zhou et al. 2009). Furthermore, PEC032 has regions that not only are conserved in $\alpha$-mannosidases but, also, share all active residues characteristic of such proteins. In accordance with predictions, PEC032 could be a CAZyme (carbohydrateactive enzyme), because this family of proteins includes hydrolases that are responsible for the degradation of $\mathrm{N}$-glycans in plants and are related with pathogenesis (Dupoiron et al. 2015). These computational predictions were corroborated by an enzymatic assay where His-tagged PEC032 could degrade the synthetic substrate 4-nitrophenyl- $\alpha$-D-mannose, demonstrating its activity as a secreted $\alpha$-mannosidase and allowing us to rename the protein PxMLE1. N-glycans are important for the

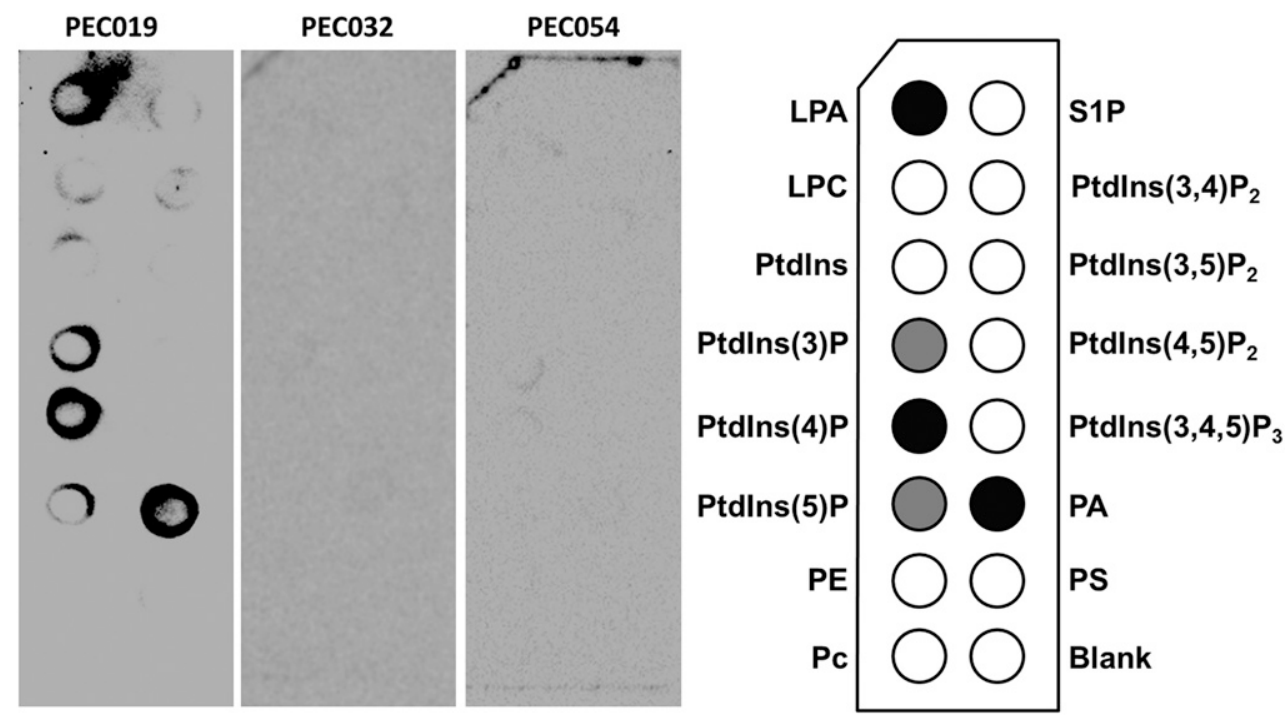

Fig. 6. Lipid-binding assay of Podosphaera xanthii effector candidates (PECs). His-tagged proteins PEC019, PEC032, and PEC054 were examined for in-vitro protein-lipid binding, using membrane strips coated with various lipids. Bound proteins were detected using anti-His antibodies. Proteins were used at 10 $\mu \mathrm{g} / \mathrm{ml}$. The assay was performed in duplicate, and representative photographs are shown. Only His-tagged PEC019 showed lipid-binding activity with strong binding to lysophosphatidic acid, phosphatidylinositol 4-phosphate, and phosphatidic acid and weak binding to phosphatidylinositol 3-phosphate and phosphatidylinositol 5-phosphate. LPA = lysophosphatidic acid, LPC = lysophosphatidylcholine, PtdIns = phosphatidylinositol, PtdIns $(\mathrm{x}) \mathrm{P}=$ phosphatidylinositol $\mathrm{x}$-phosphate, $\mathrm{PE}=$ phosphatidylethanolamine, $\mathrm{PC}=$ phosphatidylcholine, $\mathrm{S} 1 \mathrm{P}=$ sphingosine 1-phosphate, $\mathrm{PtdIns}(\mathrm{x}, \mathrm{x}) \mathrm{P}_{2}=$ phosphatidylinositol $\mathrm{x}, \mathrm{X}$-biphosphate, PtdIns $(3,4,5) \mathrm{P}_{3}=$ phosphatidylinositol 3,4,5-triphosphate, $\mathrm{PA}=$ phosphatidic acid, and PS $=$ phosphatidylserine. 
biological activity and structure of eukaryotic proteins, inducing correct folding and preventing proteolytic degradation (Rayon et al. 1998). Therefore, an effector with $\alpha$-mannosidase activity that degrades the $\mathrm{N}$-glycan would affect not only the correct folding of host proteins but also their activities and could be an important weapon for a given pathogen, particularly for obligate biotrophs. Effectors that act directly on host proteins have been identified in several pathogenic fungi, including powdery mildews (Ahmed et al. 2015; Pennington et al. 2016; Schmidt et al. 2014; Zhang et al. 2012), many of them acting as proteases or protease inhibitors (Jashni et al. 2015). Thus, that powdery mildews secrete $\alpha$-mannosidase-like effectors could be an additional strategy in the general plan of modification and alteration of host cell functions. If so, the high number of potential targets might explain its high expression levels. Moreover, MLE1 proteins seem to be widely conserved in Ascomycetes, suggesting a conserved role of $\alpha$-mannosidaselike effectors.

PEC054 seems to be a cerato-platanin-like protein. Such proteins are only present in fungi, mostly in plant pathogens, but they have also been identified in mycorrhizal fungi, saprotrophs, and human pathogens (Baccelli 2015). HIGS assays showed that PECO54 silencing resulted in the activation of plant defense responses accompanied by a significant reduction of fungal growth, similar to that observed for MSP1, a ceratoplatanin protein from Magnaporthe grisea (Jeong et al. 2007). However, in other filamentous fungi, the knockout of ceratoplatanin-coding genes caused a completely opposite effect; these proteins act as PAMPs (pathogen-associated molecular patterns) (Baccelli 2015; Jeong et al. 2007). To date, three

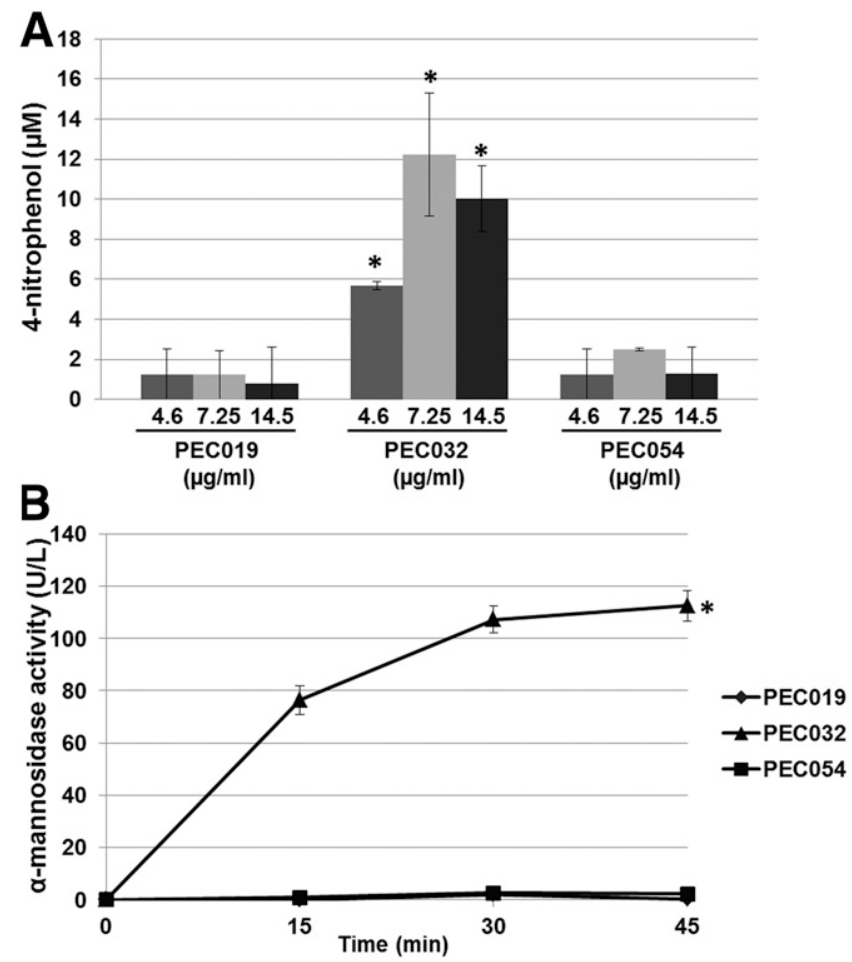

Fig. 7. In-vitro analysis of $\alpha$-mannosidase activity of His-tagged Podosphaera xanthii effector candidates (PECs). His-tagged proteins PEC019, PEC032, and PEC054 were examined for in-vitro $\alpha$-mannosidase activity, using a colorimetric assay and 4-nitrophenyl- $\alpha$-D-mannopyranoside as a substrate. A, Determinations of 4-nitrophenol after $10 \mathrm{~min}$ of reaction. $\mathbf{B}$, Time course analysis of $\alpha$-mannosidase activity, using proteins at $32 \mu \mathrm{g} / \mathrm{ml}$. Data represents the mean of three independent assays. Error bars represent the standard error. The asterisk indicates a statistically significant difference between the samples according to Student's $t$ test $(P<0.01)$. different roles have been hypothesized for cerato-platanin proteins: i) participation in the growth and development of the fungus, ii) protection of the fungal cell wall, and iii) interaction with host-defense responses (Baccelli 2015).

According to our predictions, the role of PEC054 could be related to a potential interaction with cellopentaose. Although this prediction seems to be in disagreement with what is observed in most of the functionally described cerato-platanin from other phytopathogenic fungi, which bind chitin polymers (Gaderer et al. 2014), our experimental data clearly
A cellopentaose

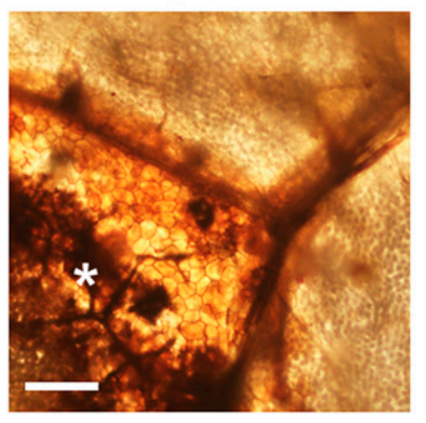

cellopentaose/PEC032

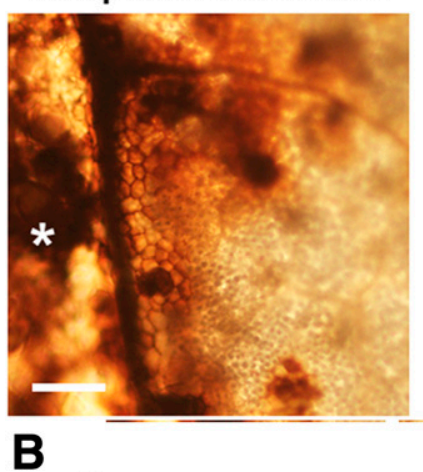

\section{cellopentaose/PEC019}

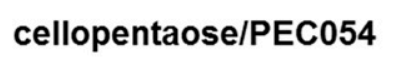

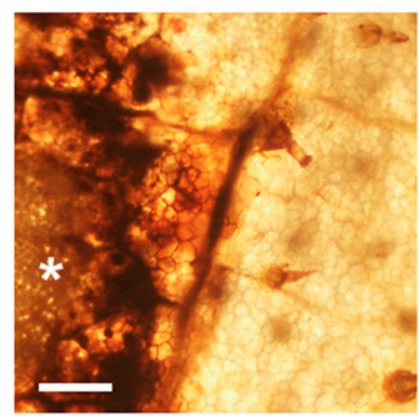
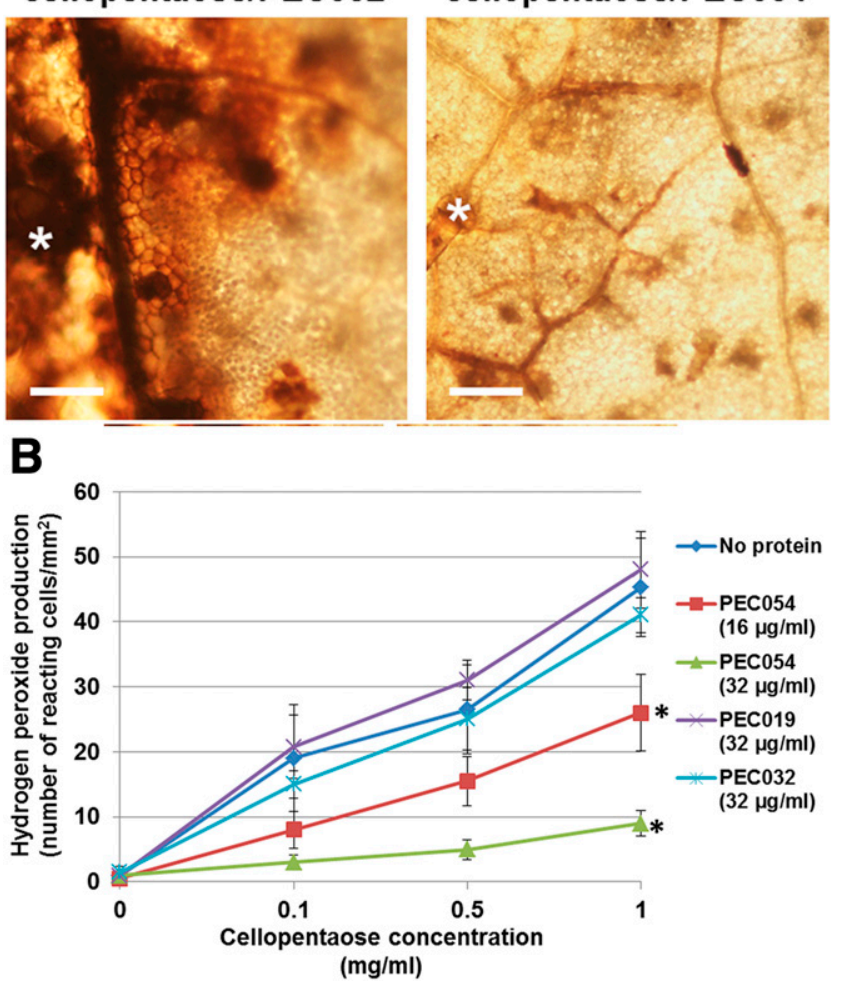

Fig. 8. Histochemical detection of hydrogen peroxide accumulation in melon leaves upon infiltration of cellopentaose and His-tagged Podosphaera xanthii effector candidates (PECs). Detection of $\mathrm{H}_{2} \mathrm{O}_{2}$ was performed by the 3,3'-diaminobenzidine-uptake method. A, Activation of cellulose-triggered immunity and suppression of this response by Histagged PEC054. Melon leaves were infiltrated with cellopentaose (1 $\mathrm{mg} / \mathrm{ml}$ ) and His-tagged proteins ( $32 \mu \mathrm{g} / \mathrm{ml})$. Photographs were taken at $24 \mathrm{~h}$ after infiltration. Asterisks denote the infiltration site. Scale bars $=200 \mu \mathrm{m}$. B, Hydrogen peroxide accumulation by epidermal cells upon infiltration of different concentrations of cellopentaose $(0.1,0.5$, and $1 \mathrm{mg} / \mathrm{ml})$ in combination with different concentrations of His-tagged proteins $(0,16$, and 32 $\mu \mathrm{g} / \mathrm{ml}$ ). The data was recorded at $24 \mathrm{~h}$ after infiltration. Data represents the mean of three independent assays. Error bars represent the standard error. The asterisk indicates a statistically significant difference from control (no protein), according to Student's $t$ test $(P<0.05)$. 
Table 6. Fungal species assessed for the presence of PLBE1, MLE1, and CLBE1 effector proteins

\begin{tabular}{|c|c|c|c|c|c|c|c|}
\hline \multirow[b]{2}{*}{ Species } & \multirow[b]{2}{*}{ Pathogenicity } & \multicolumn{2}{|c|}{ PLBE1 } & \multicolumn{2}{|c|}{ MLE1 } & \multicolumn{2}{|c|}{ CLBE1 } \\
\hline & & Identity (\%) & Accession no. & Identity (\%) & Accession no. & Identity (\%) & Accession no. \\
\hline \multicolumn{8}{|l|}{ Ascomycetes-Sordariomycetes } \\
\hline $\begin{array}{l}\text { Colletotrichum } \\
\text { gloeosporioides }\end{array}$ & Plant pathogen & 48 & EQB50345.1 & 68 & EQB48804.1 & 58 & EQB47844.1 \\
\hline Fusarium graminearum & Plant pathogen & 46 & XP_011322261.1 & 66 & XP_011321365.1 & 58 & XP_011325136.1 \\
\hline Fusarium oxysporum & Plant pathogen & 46 & EGU74663.1 & 67 & EWY85085.1 & 55 & EWZ31181.1 \\
\hline Magnaporthe oryzae & Plant pathogen & 53 & XP_003710617.1 & 62 & XP_003719702.1 & 62 & XP_003710181.1 \\
\hline Nectria hematococca & Plant pathogen & 49 & XP_003048917.1 & 67 & XP_003045040.1 & 57 & XP_003040503.1 \\
\hline Neurospora crassa & Plant pathogen & 45 & XP_964220.2 & 62 & XP_964439.2 & 49 & XP_958708.1 \\
\hline Rosellinia necatrix & Plant pathogen & 50 & GAP84448.1 & 64 & GAP90426.2 & 59 & GAP91833.1 \\
\hline Verticillium longisporum & Plant pathogen & 43 & CRK28720.1 & 66 & CRK45387.1 & 52 & CRK28030.1 \\
\hline Podospora anserina & Saprophyte & 53 & XP_001912932.1 & 62 & XP_001910384.1 & 49 & XP_001911154.1 \\
\hline Stachybotrys chartarum & Saprophyte & 49 & KEY70655.1 & 66 & KEY66609.1 & 53 & KEY72040.1 \\
\hline Trichoderma reesei & Saprophyte & 43 & XP_006964057.1 & 62 & XP_006962241.1 & 57 & XP_006970000.1 \\
\hline Beauveria bassiana & Entomopathogen & - & - & 65 & KGQ09834.1 & 53 & KGQ05080.1 \\
\hline Cordyceps militaris & Entomopathogen & - & - & 63 & XP_006665646.1 & 56 & XP_006674418.1 \\
\hline Metarhizium album & Entomopathogen & - & - & 62 & KHN99303.1 & 51 & OSD0̄01722.1 \\
\hline $\begin{array}{l}\text { Torrubiella } \\
\text { hemipterigena }\end{array}$ & Entomopathogen & - & - & 65 & NP_594648.1 & - & - \\
\hline \multicolumn{8}{|l|}{ Ascomycetes-Eurotiomycetes } \\
\hline Aspergillus niger & $\begin{array}{l}\text { Opportunistic } \\
\text { mammalian } \\
\text { pathogen }\end{array}$ & - & - & 62 & XP_001402231.1 & 56 & GAQ35095.1 \\
\hline Aspergillus oryzae & $\begin{array}{l}\text { Opportunistic } \\
\text { mammalian } \\
\text { pathogen }\end{array}$ & - & - & 65 & XP_001822384.1 & 53 & XP_001821825.2 \\
\hline Coccidioides immitis & $\begin{array}{c}\text { Mammalian } \\
\text { pathogen }\end{array}$ & - & - & 63 & XP_001239831.1 & 47 & KMU74303.1 \\
\hline $\begin{array}{l}\text { Rhinocladiella } \\
\text { mackenziei }\end{array}$ & $\begin{array}{c}\text { Mammalian } \\
\text { pathogen }\end{array}$ & - & - & 55 & XP_013275883.1 & - & - \\
\hline \multicolumn{8}{|c|}{ Ascomycetes-Dothideomycetes } \\
\hline Pseudogymnoascus sp. & Saprophyte & 53 & KFY63249.1 & 70 & KFX93790.1 & 63 & KFY12751.1 \\
\hline Alternaria alternata & Plant pathogen & 48 & XP_018383135.1 & 62 & XP_018385640.1 & 54 & XP_018391527.1 \\
\hline Bipolaris maydis & Plant pathogen & 49 & XP_014080143.1 & 63 & XP_014084614.1 & 60 & XP_014078725.1 \\
\hline Leptosphaeria maculans & Plant pathogen & 43 & XP_003837080.1 & 61 & XP_003837414.1 & 51 & AAM33130.1 \\
\hline $\begin{array}{l}\text { Mycosphaerella } \\
\text { graminicola }\end{array}$ & Plant pathogen & - & - & 65 & $\mathrm{JGI}^{\mathrm{a}}$ & 46 & JGI \\
\hline \multicolumn{8}{|l|}{ Ascomycetes-Letiomycetes } \\
\hline $\begin{array}{l}\text { Blumeria graminis f. sp. } \\
\quad \text { hordei }\end{array}$ & Plant pathogen & - & - & 71 & CCU75902.1 & 59 & CCU76194.1 \\
\hline Botrytis cinerea & Plant pathogen & 62 & XP_001550672.1 & 69 & XP_001550285.1 & 61 & XP_001559499.1 \\
\hline Erysiphe necator & Plant pathogen & 50 & KHJ30580.1 & 73 & KHJ33192.1 & 61 & KHJ35849.1 \\
\hline Glarea lozoyensis & Plant pathogen & 63 & ЕНК98049.1 & 74 & XP_008076610.1 & 58 & XP_008081897.1 \\
\hline Sclerotinia sclerotiorum & Plant pathogen & 51 & XP_001587094.1 & 69 & XP_001590555.1 & 61 & XP_001588549.1 \\
\hline \multicolumn{8}{|c|}{ Ascomycetes-Saccharomycetes } \\
\hline Candida albicans & $\begin{array}{l}\text { Opportunistic } \\
\text { mammalian } \\
\text { pathogen }\end{array}$ & - & - & 50 & KHC31273.1 & - & - \\
\hline $\begin{array}{l}\text { Lodderomyces } \\
\text { elongisporus }\end{array}$ & $\begin{array}{l}\text { Opportunistic } \\
\text { mammalian } \\
\text { pathogen }\end{array}$ & - & - & 45 & XP_001523244.1 & - & - \\
\hline $\begin{array}{l}\text { Schizosaccharomyces } \\
\text { pombe }\end{array}$ & Saprophyte & - & - & 53 & NP_594648.1 & - & - \\
\hline \multicolumn{8}{|c|}{ Basidiomycetes-Homobasidiomycetes } \\
\hline Phanerochaete carnosa & Saprophyte & 46 & XP_007400757.1 & - & - & 59 & XP_007392654.1 \\
\hline \multicolumn{8}{|c|}{ Basidiomycetes-Agaricomycetes } \\
\hline Auricularia subglabra & Saprophyte & 44 & XP_007337594.1 & 44 & XP_007338194.1 & 51 & XP_007337041.1 \\
\hline Coprinosis cinerea & Saprophyte & 50 & XP_002910642.1 & - & - & 51 & XP_001839821.2 \\
\hline $\begin{array}{l}\text { Cryptococus } \\
\text { amylolentus }\end{array}$ & Saprophyte & 49 & ODO09573.1 & - & - & - & - \\
\hline Dichomitus squalens & Saprophyte & 44 & XP_007368118.1 & 44 & XP_007364328.1 & 54 & XP_007364464.1 \\
\hline $\begin{array}{l}\text { Cryptococus } \\
\text { neoformans }\end{array}$ & $\begin{array}{l}\text { Opportunistic } \\
\text { mammalian } \\
\text { pathogen }\end{array}$ & - & - & - & - & - & - \\
\hline Ustiago maydis & Plant pathogen & - & - & 43 & JGI & - & - \\
\hline \multicolumn{8}{|c|}{ Basidiomycetes-Pucciniomycetes } \\
\hline Puccinia graminis & Plant pathogen & 34 & XP_003329876.2 & - & - & - & - \\
\hline \multicolumn{8}{|c|}{ Basidiomycetes-Urediniomycetes } \\
\hline $\begin{array}{l}\text { Melampsora larici- } \\
\text { populina }\end{array}$ & Plant pathogen & 43 & XP_007406856.1 & - & - & - & - \\
\hline Melampsora lini & Plant pathogen & 38 & JGI & - & - & - & - \\
\hline
\end{tabular}

a JGI = Joint Genome Institute fungal database. 
showed that PEC054 only presented high affinity for cellulose and, as observed in silencing experiments, the cerato-platanin from $P$. xanthii showed a different role to that described in other species of phytopathogenic fungi. Cellopentaose is a cellodextrin comprising five glucose monomers. Cellodextrins are compounds derived from cellulose degradation of the plant cell wall (Vallarino and Osorio 2012). Plants can detect PAMPs and molecules resulting from the degradation of the cell wall, such as cellulose polymers and pectin-derived oligogalacturonides, the so-called damage-associated molecular patterns (Vallarino and Osorio 2012). As such, cellodextrins have previously been reported to induce immune responses in grapevine depending on the degree of polymerization (Pogorelko et al. 2013). Consequently, we tested the predicted activity of PEC054 as a scavenger of cellulose polymers. Indeed, the coinfiltration of melon leaves with His-tagged PEC54 and cellopentaose suppressed the elicitation of cellulose-triggered immunity, corroborating the computational predictions and suggesting that the function of PEC054 (now renamed PxCLBE1) is the scavenging of cellodextrins released during the degradation of the plant cell wall at the penetration sites, thus avoiding the activation of cellulose-dependent defense responses of the plant.

This type of activity is very important for the survival of a pathogen in the plant environment. As previously documented, the function of sequestering small polymers that trigger plant defense responses is a key role played by certain effectors. One of those is Ecp6, an effector secreted by Cladosporium fulvum that sequesters chitin polymers released from the fungal cell wall, resulting from the activity of host chitinases to avoid being recognized by chitin receptors, the plant being unable to activate the chitin-triggered immunity (de Jonge et al. 2010). In this context, the role of PxCLBE1 would be consistent with the lifestyle of powdery mildews, whose main purpose and 'cornerstone' of survival is to go unnoticed by the plant's immune response. Surprisingly, CLBE1 proteins seem to also be present in mammalian and insect pathogens, suggesting additional roles for these proteins besides cellulose binding and suppression of cellulose-triggered immunity.

The function of the remaining candidates has not been experimentally addressed in this study. Nevertheless, we have provided interesting data to support further studies. PEC007 silencing showed a clearly distinct pattern compared with the remaining candidate effectors analyzed; gene-silencing effects on fungal growth and activation of plant responses were delayed. According to computational predictions PEC007 could play a role in the pathogen-plant interaction, acting as a putative methyltransferase. Moreover, its structure is very similar to MetRS from Pyrococcus abyssi, a protein that plays an essential role in initiating translation by transferring methionine to initiator transfer RNA (tRNA) (Kwon et al. 2011). Interestingly, methyltransferases are characterized by their ability to transfer methyl groups from a donor such as $S$ adenosylmethionine to a receiver that may be proteins such as histones and nucleic acids, DNA, or RNA (Hori 2014; Silmon de Monerri and Kim 2014). Histone modification or methylation of DNA or RNA regulates the accessibility of the transcriptional machinery to DNA, regulating gene expression (Silmon de Monerri and Kim 2014). Previous studies have shown that these epigenetic modifications are exploited by several pathogens, which secrete methyltransferase-like effectors inside host cells, promoting the deregulation of the expression of certain genes (Pennini et al. 2010; Rolando et al. 2013). Accordingly, we speculate that PEC007 could belong to this class of methyltransferase-like effectors.

Silencing of PECO34 resulted in a strong reduction of fungal growth and induction of an intermediate activation of plant defense responses, comparable to the silencing of the CmMlol gene. The protein model of PEC034 showed a high homology with the human protein ALIX and Bro1, its ortholog in yeast (Pashkova et al. 2013; Zhai et al. 2011). These proteins, also present in plants, are characterized by the participation in processes essential for cell life, such as the trafficking of endosomes and multivesicular bodies, prevention of apoptosis, and regulation of the traffic of phosphate transporters, intracellular traffic, and degradation of the membrane proteins (Cardona-López et al. 2015; Kalinowska et al. 2015; Odorizzi 2006; Zhai et al. 2011). Interestingly, exploitation of ALIXlike proteins has been previously described in viral and bacterial infections, modulating the host vesicle trafficking (Asrat et al. 2014; Zhai et al. 2011). This regulation seems to be important for obligate biotrophs, because it has been previously described that plants accumulate many organelles, such as mitochondria, the Golgi apparatus, nuclei, and endoplasmic reticulum close to the haustoria (Caillaud et al. 2012). In addition, extensive trafficking has been observed of vesicles and multivesicular bodies accumulating antimicrobial compounds and papilla components, which will be secreted by the plant at the penetration sites (An et al. 2006). Interestingly, the PEC034 model has great similarity to the melon ALIX protein model, despite showing great differences in their sequence. Previous studies have observed that pathogens can mimic, functionally and structurally, host proteins, despite having completely different sequences, to manipulate host cell mechanisms (Stebbins and Galán 2001). Therefore, we hypothesize that PEC034 could be an effector that mimics host ALIX protein to manipulate the regulation of plant vesicle trafficking and, thereby, to promote the establishment of the disease.

The putative role of PEC009, whose protein model and ligand predictions suggested that it could act as a transcription factor, is framed in a similar line. The protein model of PEC009 showed homology with the human PSPC1, a protein involved in transcriptional and posttranscriptional gene regulatory functions, influencing various biological processes (Passon et al. 2012). The possibility that $P$. xanthii could express effectors with a role in the regulation of transcription would not be a surprise. In infections caused by various pathogens, transcriptional changes modulated by the pathogens to improve their own survival have been observed. For example, the ability of Plasmodium spp. to induce changes in the transcription of more than 1,000 host genes is well-known (Silmon de Monerri and Kim 2014). However, in the case of fungal pathogens, little is known about effectors manipulating the transcriptional regulation of the host cell. It is interesting to note that both PEC034 and PECO09 play an important role in the establishment of disease, especially PECO09, whose silencing not only triggered a drastic and early defense response in the plant but, also, caused a rapid reduction of the fungal growth similarly observed for the positive control for RNAi-induced resistance, the RNAi silencing of melon CmMlol. Therefore, it would be interesting to conduct additional studies on this type of effector to identify their plant targets and plant genes that might be regulated.

To summarize, in this work, we have analyzed for the first time the role of some candidate effectors of $P$. xanthii, one of the most important pathogens of cucurbits. By means of an in-vivo functional analysis by ATM-HIGS and an in silico analysis combining different computational tools, we have concluded that PEC007, PEC009, PEC019, PEC032, PEC034, and PEC054 are true effectors and formulated different hypotheses concerning the role of these candidates in the plant-fungus interaction. Moreover, the biochemical activity of three of these effectors, PEC019, PEC032, and PEC054, was demonstrated, confirming the computational predictions and 
identifying novel functions for powdery mildew effectors, such as phospholipid-binding protein (PEC019/PxPLBP1), $\alpha$-mannosidase (PEC032/PxMLE1), and cellulose-binding protein (PEC054/PxCLBE1). More interestingly, the wide distribution of these three effector proteins among fungal pathogens reinforces the idea that their functions must be crucial for pathogenesis and survival of the fungi during plant colonization.

\section{MATERIALS AND METHODS}

\section{Plants, microbes, and culture conditions.}

Podosphaera xanthii isolate 2086 was cultured on zucchini (Cucurbita pepo L.) cotyledons from cv. Negro Belleza (Semillas Fitó, Barcelona, Spain) that were maintained in $8-\mathrm{cm}$ petri dishes under a 16 -h light and 8 -h dark cycle at $22^{\circ} \mathrm{C}$ for 1 week (Álvarez and Torés 1997). For HIGS assays, melon cotyledons from cv. Rochet Panal (Semillas Fitó) were used. For agroinfiltration, Agrobacterium tumefaciens C58C1 was used. The strain was routinely grown in Luria Bertani (LB) medium at $28^{\circ} \mathrm{C}$. The antibiotics rifampicin $(50 \mu \mathrm{g} / \mathrm{ml})$, kanamycin $(50 \mu \mathrm{g} / \mathrm{ml})$, and spectinomycin $(100 \mu \mathrm{g} / \mathrm{ml})$ were used when required. For plasmid construction and protein expression, the Escherichia coli strains DH5 $\alpha$ and BL21-AI were used. These strains were grown at $37^{\circ} \mathrm{C}$ in $\mathrm{LB}$ containing spectinomycin $(100 \mu \mathrm{g} / \mathrm{ml})$ or ampicillin $(100 \mu \mathrm{g} / \mathrm{ml})$.

\section{Analysis of PEC sequences.}

The search of homologous sequences and identification of putative conserved domains were conducted using the DELTABLAST (Domain Enhanced Lookup Time Accelerated BLAST) tool at the National Center of Biotechnology Information website. The prediction of SP and transmembrane domains was carried out using the SignalP 4.1 server (Petersen et al. 2011) and TMHMM server v. 2.0, respectively. Alignments using amino acid sequences were conducted using Clustal X software (Larkin et al. 2007).

\section{Plasmids used and construction of gene silencing vectors.}

The plasmids used in this study are listed in Table 2. All the plasmids carry the T-DNA construct under the control of the CaMV 35S promoter (Fig. 2). The plasmid pGWB6 ( $g f p$ expression) was used for the visualization of transformed tissue by fluorescence analysis (Nakagawa et al. 2007). The plasmid pB7GWIWG2 (II) (Karimi et al. 2002) was used for the construction of candidate effector gene silencing vectors. The plasmid pGWB2 was used as a negative control (empty vector) in HIGS assays.

Gene silencing and expression vectors were constructed using the Gateway cloning system (Invitrogen, Carlsbad, CA, U.S.A.). For the construction of gene silencing vectors, a fragment for each effector gene was amplified from cDNA, obtained as shown below, using specific primers with attB1 or attB2 tails (Supplementary Table S1). The PCR products obtained were reamplified with attB1 and attB2 primers to add the att sequences to both ends. The final PCR products were introduced into the pDONR201 donor vector (Invitrogen) by $B P$ reaction. Next, the PCR products were integrated into the binary vector $\mathrm{pB} 7 \mathrm{GWIWG} 2$ (II) by LR reaction. Recombination reactions were performed as described in the manufacturer's instructions (Invitrogen). The construction, propagation, and amplification of the gene-silencing vectors were carried out in E. coli DH5 $\alpha$. Finally, the silencing vectors were introduced into A. tumefaciens $\mathrm{C} 58 \mathrm{C} 1$ by electroporation and were verified by PCR and digestion. This way, the vectors pPEC007-HIGS, pPEC008-HIGS, pPEC009-HIGS, pPEC019HIGS, pPEC032-HIGS, pPEC034-HIGS, and pPEC054-HIGS were constructed.
In the case of protein expression vectors, the primer pairs 019trun-F/019-R, 032trun-F/032-R, and 054trun-F/054-R were used to amplify the full-length of PEC019 (528 pb), PEC032 (1,569 pb), and PEC054 (360 pb), respectively, without the SP. The PCR products obtained were reamplified with attB1 and attB2 primers and were introduced into the pDONR201 donor vector by BP reaction. Next, the PCR products were integrated into the expression vector pDEST17 (Invitrogen) by LR reaction. The obtained vectors pPEC019-EXPR, pPEC032-EXPR, and pPEC054-EXPR were maintained in E. coli DH5 $\alpha$ and were verified by sequencing. To conduct His-tagged protein expression, the vectors were introduced into E. coli BL21-AI (Invitrogen) by electroporation.

\section{ATM-HIGS assay.}

For ATM-HIGS experiments, two different T-DNA constructs were used, pGWB6 (to detect transformed tissue by GFP fluorescence) and the corresponding candidate effector gene silencing vector. Prior to agroinfiltration, A. tumefaciens C58C1 cells containing the plasmids were induced with acetosyringone (Michielse et al. 2008). Bacterial cells were grown overnight at $28^{\circ} \mathrm{C}$, in $5 \mathrm{ml}$ of $\mathrm{LB}$ medium containing the corresponding antibiotics, in an orbital shaker at $200 \mathrm{rpm}$. Subsequently, bacterial cultures were washed twice in washing buffer (95\% IM buffer [50 mM MES, pH 5.6, $0.5 \%$ glucose, $\left.2 \mathrm{mM} \mathrm{NaH}_{2} \mathrm{PO}_{4}\right], 5 \% 20 \times \mathrm{AB}$ salt buffer $\left[0.38 \mathrm{M} \mathrm{NH}_{4} \mathrm{Cl}, 0.4 \mathrm{M} \mathrm{MgSO}_{4} \cdot 7 \mathrm{H}_{2} \mathrm{O}, 0.8 \mathrm{M} \mathrm{KCl}, 1.8 \mathrm{mM}\right.$ $\left.\mathrm{CaCl}_{2}, 0.18 \mathrm{mM} \mathrm{FeSO} \cdot \cdot 7 \mathrm{H}_{2} \mathrm{O}\right]$, and $200 \mu \mathrm{M}$ acetosyringone) and were incubated for $2 \mathrm{~h}$ at $28^{\circ} \mathrm{C}$ in an orbital shaker at $200 \mathrm{rpm}$, to induce Vir proteins. Finally, bacterial suspensions were centrifuged at $1,800 \times g$ for $10 \mathrm{~min}$ at $28^{\circ} \mathrm{C}$ and were resuspended in MES buffer (10 mM MES, $10 \mathrm{mM} \mathrm{MgCl}_{2}$, and $200 \mu \mathrm{M}$ acetosyringone). For agroinfiltration, A. tumefaciens cultures were adjusted to an optical density at $600 \mathrm{~nm}\left(\mathrm{OD}_{600}\right)$ of 1.0 in MES buffer, as previously described (Goodin et al. 2002).

For ATM-HIGS experiments, melon cotyledons were coinfiltrated with the corresponding gene-silencing construct and pGWB6. For coinfiltration, equal volumes of each bacterial suspension were mixed prior to infiltration. Next, the bacterial suspensions were infiltrated with an insulin needleless syringe into the abaxial leaf surface. After agroinfiltration, the infiltrated cotyledons were maintained in a growth chamber at $25^{\circ} \mathrm{C}$, with a 16 -h light and 8 -h dark cycle for $24 \mathrm{~h}$. After this incubation, agroinfiltrated cotyledons were infected by pulverization with fresh suspensions of $1 \times 10^{5}$ conidia per milliliter and were maintained in a growth chamber, at $25^{\circ} \mathrm{C}$ with a 16-h light and 8-h dark cycle, until microscopy analysis. RNAi silencing of the melon $C m M L O 1$ gene was used as a positive control for RNAi-induced resistance. An empty silencing vector (pGWB2) was always used as a negative control in these experiments.

\section{Epifluorescence microscopy.}

To detect transformed tissue, cotyledons were analyzed under a Nikon AZ-100 epifluorescence microscope (Nikon, Tokyo) equipped with a filter suitable for GFP analysis. The samples were excited using a light with 460- to 500-nm wavelengths, and a fixed exposure of $2 \mathrm{~s}$ was used. The images were captured with a Nikon digital Slight DS-5Mc camera attached to the microscope and were processed using the NisElements software (Nikon).

\section{Histochemical detection} of hydrogen peroxide and haustorial count.

The in-situ accumulation of hydrogen peroxide $\left(\mathrm{H}_{2} \mathrm{O}_{2}\right)$ was determined by histochemical analysis according to the 
3,3' $3^{\prime \prime}$ diaminobenzidine (DAB)-uptake method (ThordalChristensen et al. 1997). Cotyledon disks of $1 \mathrm{~cm}$ in diameter were incubated in $1 \mathrm{mg}$ of DAB per milliliter ( $\mathrm{pH} 3.8$ ) (SigmaAldrich, St. Louis) overnight, in the dark, at room temperature. After incubation, the leaf disks were treated with boiling ethanol to stop the reaction and clear the disks. Finally, the leaf disks were analyzed under a bright field microscope for brownish-red precipitates corresponding to $\mathrm{H}_{2} \mathrm{O}_{2}$ accumulation. In the same disks the progress of the $P$. xanthii infection was microscopically assessed. The haustoria were visualized as dark brown spots beneath the $P$. xanthii hyphae inside epidermal cells.

\section{RNA extraction and cDNA synthesis.}

Total RNA was isolated from samples, using a TRI Reagent RNA isolation system (Sigma-Aldrich) according to the manufacturer's instructions. The RNA concentration was estimated using the NanoDrop spectrophotometer ND-1000 (Thermo Scientific, Waltham, MA, U.S.A.). For the elimination of contaminating DNA, the TURBO DNA-free kit (Invitrogen) was used. cDNAs were synthetized using Superscript III Reverse transcription (Invitrogen) and the Oligo $\mathrm{dT}(20)$ primer (Invitrogen) according to the manufacturer's recommendations.

\section{DNA isolation and purification.}

Total DNA was isolated from agroinfiltrated melon cotyledons was inoculated with $P$. xanthii. The samples were taken at $72 \mathrm{hpi}$ and were immediately frozen in liquid nitrogen and were macerated in a mortar with pestle. Total DNA was extracted, using a TRI Reagent isolation system (Sigma-Aldrich) according to the manufacturer's instructions.

\section{Quantitative reverse transcription (qRT)-PCR and qPCR.}

The quantification of the gene expression of each PEC gene during the early stages of fungal infection was analyzed by qRT-PCR, using the cDNA obtained as described above from melon leaves. The $P$. xanthii $\beta$-tubulin gene PxTUB2 (KC333362) was used as reference gene for normalization of transcript expression. To investigate the expression of silencing constructions in the plant, cDNA from noninfected melon cotyledons $24 \mathrm{~h}$ after agroinfiltration was used to conduct a qRT-PCR analysis using pairs of primers. The Cucumis melo actin gene (XM_008462689.2) was used as a reference gene. The effects of gene silencing in the expression of PEC genes during HIGS assays were analyzed by qRT-PCR, using cDNA obtained from agroinfiltrated and $P$. xanthii-infected melon cotyledons at 24 hpi. The $P$. xanthii $\beta$-tubulin gene PXTUB2 was used as a reference gene. qRT-PCR reactions were conducted in a CFX384 Touch real-time PCR detection system (Bio-Rad, Hercules, CA, U.S.A.), using SsoFast EvaGreen supermix according to the manufacture's recommendations (Bio-Rad). The qRT-PCR conditions were as follows: enzyme activation step at $95^{\circ} \mathrm{C}$ for $30 \mathrm{~s}$, followed by 40 cycles of $5 \mathrm{~s}$ at $95^{\circ} \mathrm{C}$ and $5 \mathrm{~s}$ at $65^{\circ} \mathrm{C}$. All reactions were performed in quadruplicate. After amplifications, the data were analyzed using CFX Manager software (Bio-Rad). Additionally, the amplicon size was confirmed by visualization on $1 \%$ agarose gels.

For molecular estimation of fungal biomass, total DNA obtained from agroinfiltrated infected melon cotyledons at 72 hpi was used as a sample for qPCR analysis. The qPCR reactions were conducted in a CFX384 Touch real-time PCR detection system, using SsoFast EvaGreen supermix according to the manufacturer's instructions. The genes quantified were the $P$. xanthii $\beta$-tubulin gene PxTUB2 and the $C$. melo actin gene. The qPCR reactions were performed as described above. After amplifications, the data were analyzed using CFX
Manager software and the amplicon size was confirmed by visualization on $1 \%$ agarose gels. Subsequently, the ratio of $P$. xanthii and $C$. melo genomic DNA was calculated as previously described (Vela-Corcía et al. 2014).

\section{Protein modeling and protein function prediction.}

The website I-TASSER (Zhang 2008) was used to perform automated protein structure homology modeling of candidate effectors, using the crystal structure of proteins available in the database as a template. I-TASSER detects structure templates from the Protein Data Bank by a technique called fold recognition. The full-length structure models are constructed by reassembling structural fragments from threading templates, using replica-exchange Monte Carlo simulations (Roy et al. 2010). The measure of the quality of a predicted structure is its estimated TM (template modeling) score. According to I-TASSER, TM score values $>0.5$ indicate a correct topology and TM score values $<0.17$ means a random similarity (Zhang 2008).

The website Phyre2 (Kelley et al. 2015) was used to carry out the search for analogous structures. Prediction function and ligands of the studied PECs was carried out using the following set of software tools: CATH/Gene3D (Lam et al. 2016), COACH (Yang et al. 2013), 3DLigandSite (Wass et al. 2010), GalaxySite, and Motif Scan.

\section{Protein expression and purification.}

Recombinant N-terminally His-tagged proteins were produced by E. coli BL21-AI harboring the plasmids pPEC019EXPR, pPEC032-EXPR, and pPEC054-EXPR. For this, E. coli BL21-AI cells were grown in LB medium supplemented with $100 \mu \mathrm{g}$ of ampicillin per milliliter, at $37^{\circ} \mathrm{C}$, until $\mathrm{OD}_{600} 0.6$ and, then, were induced with $0.2 \%$ L-(+)-Arabinose (SigmaAldrich), followed by incubation overnight at $16^{\circ} \mathrm{C}$ in an orbital shaker at $120 \mathrm{rpm}$. For PEC054 expression, E. coli BL21-AI cells were incubated at $25^{\circ} \mathrm{C}$ for $3 \mathrm{~h}$ after induction. Next, His-tagged proteins were purified using HIS-Select nickel affinity gel (Sigma-Aldrich). Finally, His-tagged proteins were dialyzed against phosphate buffered saline (PBS) using the Slide-A-Lyzer dialysis cassette G2 20K/20 ml or $10 \mathrm{~K} / 15 \mathrm{ml}$ (Thermo Scientific), according to the expected size. Protein purification was confirmed using sodium dodecyl sulfate-polyacrylamide gel electrophoresis. Protein concentrations were calculated using the extinction coefficients and molecular weights obtained from ExPASy and the absorbance was measured at $280 \mathrm{~nm}$ in a S-22 UV/Vis spectrophotometer (BOECO, Hamburg, Germany).

\section{Lipid-binding assay.}

PIP strip membranes (Thermo Scientific) were used to visualize the binding preference of His-tagged PEC019 to different lipids. Lipid-binding assay was performed according to the manufacturer's protocol. His-tagged PEC032 and PEC054 proteins were used as negative controls. His-tagged proteins were used at $10 \mu \mathrm{g} / \mathrm{ml}$. As primary and secondary antibodies, an anti-His-tag rabbit monoclonal antibody (Rockland, Limerick, PA, U.S.A.) and an antirabbit antibody conjugated to horseradish peroxidase (Bio-Rad) were used at 1:1,000 and 1:20,000 dilutions, respectively. The membrane-bound proteins were detected using the SuperSignal West Femto chemiluminescent substrate (Thermo Scientific), following the supplier's recommended protocol.

\section{$\alpha$-Mannosidase assay.}

The activity of His-tagged PEC032 was assayed using an $\alpha$-Mannosidase activity assay kit (Sigma-Aldrich), a colorimetric assay that contains 4-nitrophenyl- $\alpha$-D-mannopyranoside 
as a substrate and determines the production of 4-nitrophenol. His-tagged PEC019 and PEC054 proteins were used as negative controls. Initially, an assay was carried out with different concentrations of purified proteins at $25^{\circ} \mathrm{C}$ for $10 \mathrm{~min}$, in a total reaction volume of $200 \mu \mathrm{l}$ in a 96-well plate, according to the manufacturer's procedure. Subsequently, a second reaction containing $14.5 \mu \mathrm{g}$ of purified protein per milliliter was carried out at $25^{\circ} \mathrm{C}$ for $45 \mathrm{~min}$ in a $1.5-\mathrm{ml}$ total volume, taking $200 \mu \mathrm{l}$ of reaction at different timepoints $(0,15,30$, and $45 \mathrm{~min})$. The $200-\mu l$ reactions were stopped with $100 \mu \mathrm{l}$ of Stop Reagent, and the absorbance was quantified on a BioWhittaker ELx808 absorbance microplate reader (Lonza, Basel, Switzerland) at $405 \mathrm{~nm}$. $\alpha$-Mannosidase activity was calculated according to manufacturer's instructions. One unit of $\alpha$-mannosidase activity is defined as the amount of enzyme that catalyzes the conversion of $1 \mu$ mole of 4-nitrophenyl- $\alpha$-D-mannopyranoside to 4-nitrophenol and $\alpha$-D-mannose per minute at $25^{\circ} \mathrm{C}$ and $\mathrm{pH} 4.5$.

\section{Cellulose-triggered immunity assay.}

To test the cellulose-binding activity of PEC054, an affinity carbohydrate binding assay was performed, using insoluble cellulose, chitin, and xylan. His-tagged PEC019 and PEC054 proteins were used as negative controls. The reactions were conducted in $250 \mu \mathrm{l}$ of $0.1 \mathrm{M}$ PBS (pH 7.0), containing $10 \mathrm{mg}$ of insoluble substrate and $40 \mu \mathrm{g}$ of purified His-tagged proteins per milliliter. The mixtures were incubated in ice for $1 \mathrm{~h}$, with stirring every $15 \mathrm{~min}$. Then, the mixtures were centrifuged at $10,000 \times g$ for $15 \mathrm{~min}$ at $4^{\circ} \mathrm{C}$. After centrifugation, two fractions were obtained, supernatants containing free protein and pellets formed by insoluble substrate and substrate-binding protein complexes. From supernatants, protein concentration was estimated as described above.

To test the cellulose scavenging activity of PEC054, melon cotyledons were infiltrated with different concentrations of cellopentaose (Megazyme, Madrid) in the presence or absence of His-tagged PEC054 protein. For this assay, different cellopentaose solutions $(0.1,0.5$, or $1 \mathrm{mg} / \mathrm{ml})$ were incubated with different His-tagged PEC054 solutions (16 or $32 \mu \mathrm{g} / \mathrm{ml}$ ) for $1 \mathrm{~h}$ in ice. His-tagged PEC019 and PEC032 proteins $(32 \mu \mathrm{g} / \mathrm{ml})$ were used as negative controls. After incubation, melon cotyledons were infiltrated using an insulin needleless syringe and were maintained in a growth chamber with a 16-h light and 8-h dark cycle at $24^{\circ} \mathrm{C}$. Plant defense responses were histochemically analyzed for the in-situ detection of $\mathrm{H}_{2} \mathrm{O}_{2}$ as described above.

\section{Statistical analysis.}

The data obtained from microscopy analyses and biochemical activity tests were analyzed by Fisher's least significant difference test and Student's $t$ test, respectively, using the statistics software tool IBM SPSS v23.0.0 (SPSS, Chicago).

\section{ACKNOWLEDGMENTS}

The authors gratefully acknowledge I. Linares (University of Malaga, Spain) for her technical assistance. Authors also thank the two reviewers of the manuscript for their constructive criticism.

\section{LITERATURE CITED}

Ahmed, A. A., Pedersen, C., Schultz-Larsen, T., Kwaaitaal, M., Jørgensen, H. J. L., and Thordal-Christensen, H. 2015. The barley powdery mildew candidate secreted effector protein CSEP0105 inhibits the chaperone activity of a small heat shock protein. Plant Physiol. 168:321-333.

Ahmed, A. A., Pedersen, C., and Thordal-Christensen, H. 2016. The barley powdery mildew effector candidates CSEP0081 and CSEP0254 promote fungal infection success. PLoS One 11:e0157586.
Ahmed, S., Bu, W., Lee, R. T. C., Maurer-Stroh, S., and Goh, W. I. 2010. F-BAR domain proteins: Families and function. Commun. Integr. Biol. 3:116-121.

Álvarez, B., and Torés, J. A. 1997. Cultivo in vitro de Sphaerotheca fuliginea (Schlecht. ex. Fr.), efecto de diferentes fuentes de carbón sobre su desarrollo. Bol. Sanid. Veg., Plagas 23:283-288.

An, Q., Hückelhoven, R., Kogel, K. H., and van Bel, A. J. E. 2006. Multivesicular bodies participate in a cell wall-associated defence response in barley leaves attacked by the pathogenic powdery mildew fungus. Cell. Microbiol. 8:1009-1019.

Asrat, S., de Jesús, D. A., Hempstead, A. D., Ramabhadran, V., and Isberg, R. R. 2014. Bacterial pathogen manipulation of host membrane trafficking. Annu. Rev. Cell Dev. Biol. 30:79-109.

Baccelli, I. 2015. Cerato-platanin family proteins: One function for multiple biological roles? Front. Plant Sci. 5:769.

Bozkurt, T. O., Richardson, A., Dagdas, Y. F., Mongrand, S., Kamoun, S., and Raffaele, S. 2014. The plant membrane-associated REMORIN1.3 accumulates in discrete perihaustorial domains and enhances susceptibility to Phytophthora infestans. Plant Physiol. 165:1005-1018.

Caillaud, M. C., Piquerez, S. J. M., Fabro, G., Steinbrenner, J., Ishaque, N., Beynon, J., and Jones, J. D. G. 2012. Subcellular localization of the Hpa RxLR effector repertoire identifies a tonoplast-associated protein HaRxL17 that confers enhanced plant susceptibility. Plant J. 69:252-265.

Caillaud, M. C., Wirthmueller, L., Sklenar, J., Findlay, K., Piquerez, S. J. M., Jones, A. M. E., Robatzek, S., Jones, J. D. G., and Faulkner, C 2014. The plasmodesmal protein PDLP1 localises to haustoriaassociated membranes during downy mildew infection and regulates callose deposition. PLoS Pathog. 10:e1004496.

Cardona-López, X., Cuyas, L., Marín, E., Rajulu, C., Irigoyen, M. L., Gil, E., Puga, M. I., Bligny, R., Nussaume, L., Geldner, N., Paz-Ares, J., and Rubio, V. 2015. ESCRT-III-Associated protein ALIX mediates high-affinity phosphate transporter trafficking to maintain phosphate homeostasis in Arabidopsis. Plant Cell 27:2560-2581.

Chaure, P., Gurr, S. J., and Spanu, P. 2000. Stable transformation of Erysiphe graminis an obligate biotrophic pathogen of barley. Nat. Biotechnol. 18:205-207.

Cheng, H., Kun, W., Liu, D., Su, Y., and He, Q. 2012. Molecular cloning and expression analysis of CmMlo1 in melon. Mol. Biol. Rep. 39:1903-1907.

Christiansen, S. K., Knudsen, S., and Giese, H. 1995. Biolistic transformation of the obligate plant pathogenic fungus, Erysiphe graminis f. sp. hordei. Curr. Genet. 29:100-102.

D’Angelo, G., Vicinanza, M., Di Campli, A., and De Matteis, M. A. 2008. The multiple roles of PtdIns(4)P-Not just the precursor of PtdIns(4,5) P2. J. Cell Sci. 121:1955-1963.

de Jonge, R., Bolton, M. D., and Thomma, B. P. 2011. How filamentous pathogens co-opt plants: The ins and outs of fungal effectors. Curr. Opin. Plant Biol. 14:400-406.

de Jonge, R., van Esse, H. P., Kombrink, A., Shinya, T., Desaki, Y., Bours, R., van der Krol, S., Shibuya, N., Joosten, M. H., and Thomma, B. P. 2010. Conserved fungal LysM effector Ecp6 prevents chitin-triggered immunity in plants. Science 329:953-955.

Dean, R., Van Kan, J. A., Pretorius, Z. A., Hammond-Kosack, K. E., Di Pietro, A., Spanu, P. D., Rudd, J. J., Dickman, M., Kahmann, R., Ellis, J., and Foster, G. D. 2012. The top 10 fungal pathogens in molecular plant pathology. Mol. Plant Pathol. 13:414-430.

Dupoiron, S., Zischek, C., Ligat, L., Carbonne, J., Boulanger, A., Dugé de Bernonville, T., Lautier, M., Rival, P., Arlat, M., Jamet, E., Lauber, E., and Albenne, C. 2015. The $N$-glycan cluster from Xanthomonas campestris pv. campestris: A toolbox for sequential plant $\mathrm{N}$-glycan processing. J. Biol. Chem. 290:6022-6036.

Gaderer, R., Bonazza, K., and Seidl-Seiboth, V. 2014. Cerato-platanins: A fungal protein family with intriguing properties and application potential. Appl. Microbiol. Biotechnol. 98:4795-4803.

Garnica, D. P., Upadhyaya, N. M., Dodds, P. N., and Rathjen, J. P. 2013. Strategies for wheat stripe rust pathogenicity identified by transcriptome sequencing. PLoS One 8:e67150.

Gillooly, D. J., Simonsen, A., and Stenmark, H. 2001. Cellular functions of phosphatidylinositol 3-phosphate and FYVE domain proteins. Biochem. J. 355:249-258

Glawe, D. A. 2008. The powdery mildews: A review of the world's most familiar (yet poorly known) plant pathogens. Annu. Rev. Phytopathol. 46:27-51.

Goodin, M. M., Dietzgen, R. G., Schichnes, D., Ruzin, S., and Jackson, A. O. 2002. pGD vectors: Versatile tools for the expression of green and red fluorescent protein fusions in agroinfiltrated plant leaves. Plant J. 31: 375-383. 
Govindarajulu, M., Epstein, L., Wroblewski, T., and Michelmore, R. W. 2015. Host-induced gene silencing inhibits the biotrophic pathogen causing downy mildew of lettuce. Plant Biotechnol. J. 13:875-883.

Gregg, K. J., Zandberg, W. F., Hehemann, J. H., Whitworth, G. E., Deng, L., Vocadlo, D. J., and Boraston, A. B. 2011. Analysis of a new family of widely distributed metal-independent alpha-mannosidases provides unique insight into the processing of N-linked glycans. J. Biol. Chem. 286:15586-15596.

Grennan, A. K. 2007. Lipid rafts in plants. Plant Physiol. 143:1083-1085.

Hacquard, S. 2014. The genomics of powdery mildew fungi: Past achievements, present status and future prospects. Adv. Bot. Res. 70: $109-142$.

Ham, H., Sreelatha, A., and Orth, K. 2011. Manipulation of host membranes by bacterial effectors. Nat. Rev. Microbiol. 9:635-646.

Harwood, W. A., Bartlett, J. G., Alves, S. C., Perry, M., Smedley, M. A., Leyland, N., and Snape, J. W. 2009. Barley transformation using Agrobacterium-mediated techniques. Methods Mol. Biol. 478:137-147.

Hong, S. W., Jiang, Y., Kim, S., Li, C. J., and Lee, D. K. 2014. Target gene abundance contributes to the efficiency of siRNA-mediated gene silencing. Nucleic Acid Ther. 24:192-198.

Hori, H. 2014. Methylated nucleosides in tRNA and tRNA methyltransferases. Front. Genet. 5:144.

Jashni, M. K., Mehrabi, R., Collemare, J., Mesarich, C. H., and de Wit, P. J. G. M. 2015. The battle in the apoplast: Further insights into the roles of proteases and their inhibitors in plant-pathogen interactions. Front. Plant Sci. 6:584.

Jeong, J. S., Mitchell, T. K., and Dean, R. A. 2007. The Magnaporthe grisea snodprot1 homolog, MSP1, is required for virulence. FEMS Microbiol. Lett. 273:157-165.

Jones, L., Riaz, S., Morales-Cruz, A., Amrine, K. C. H., McGuire, B., Gubler, W. D., Walker, M. A., and Cantu, D. 2014. Adaptive genomic structural variation in the grape powdery mildew pathogen, Erysiphe necator. BMC Genomics 15:1081.

Kale, S. D., Gu, B., Capelluto, D. G. S., Dou, D., Feldman, E., Rumore, A., Arredondo, F. D., Hanlon, R., Fudal, I., Rouxel, T., Lawrence, C. B., Shan, W., and Tyler, B. M. 2010. External lipid PI3P mediates entry of eukaryotic pathogen effectors into plant and animal host cells. Cell 142: 284-295.

Kalinowska, K., Nagel, M. K., Goodman, K., Cuyas, L., Anzenberger, F., Alkofer, A., Paz-Ares, J., Braun, P., Rubio, V., Otegui, M. S., and Isono, E. 2015. Arabidopsis ALIX is required for the endosomal localization of the deubiquitinating enzyme AMSH3. Proc. Natl. Acad. Sci. U.S.A. 112: E5543-E5551.

Karimi, M., Inzé, D., and Depicker, A. 2002. GATEWAY vectors for Agrobacterium-mediated plant transformation. Trends Plant Sci. 7: 193-195.

Kelley, L. A., Mezulis, S., Yates, C. M., Wass, M. N., and Sternberg, M. J. 2015. The Phyre 2 web portal for protein modeling, prediction and analysis. Nat. Protoc. 10:845-858.

Kim, H., O'Connell, R., Maekawa-Yoshikawa, M., Uemura, T., Neumann, U., and Schulze-Lefert, P. 2014. The powdery mildew resistance protein RPW8.2 is carried on VAMP721/722 vesicles to the extrahaustorial membrane of haustorial complexes. Plant J. 79:835-847.

Kwon, N. H., Kang, T., Lee, J. Y., Kim, H. H., Kim, H. R., Hong, J., Oh, Y. S., Han, J. M., Ku, M. J., Lee, S. Y., and Kim, S. 2011. Dual role of methionyl-tRNA synthetase in the regulation of translation and tumor suppressor activity of aminoacyl-tRNA synthetase-interacting multifunctional protein-3. Proc. Natl. Acad. Sci. U.S.A. 108:19635-19640.

Lacroix, B., and Citovsky, V. 2016. A functional bacterium-to-plant DNA transfer machinery of Rhizobium etli. PLoS Pathog. 12:e1005502.

Lam, S. D., Dawson, N. L., Das, S., Sillitoe, I., Ashford, P., Lee, D., Lehtinen, S., Orengo, C. A., and Lees, J. G. 2016. Gene3D: Expanding the utility of domain assignments. Nucleic Acids Res. 44 (D1): D404-D409.

Larkin, M. A., Blackshields, G., Brown, N. P., Chenna, R., McGettigan, P. A., McWilliam, H., Valentin, F., Wallace, I. M., Wilm, A., Lopez, R., Thompson, J. D., Gibson, T. J., and Higgins, D. G. 2007. Clustal W and Clustal X version 2.0. Bioinformatics 23:2947-2948.

Lo Presti, L., Lanver, D., Schweizer, G., Tanaka, S., Liang, L., Tollot, M., Zuccaro, A., Reissmann, S., and Kahmann, R. 2015. Fungal effectors and plant susceptibility. Annu. Rev. Plant Biol. 66:513-545.

Martínez-Cruz, J., Romero, D., Dávila, J. C., and Pérez-García, A. 2014. The Podosphaera xanthii haustorium, the fungal Trojan horse of cucurbit-powdery mildew interactions. Fungal Genet. Biol. 71:21-31.

Martínez-Cruz, J., Romero, D., de Vicente, A., and Pérez-García, A. 2017. Transformation of the cucurbit powdery mildew pathogen Podosphaera xanthii by Agrobacterium tumefaciens. New Phytol. 213:1961-1973.
Menardo, F., Praz, C. R., Wicker, T., and Keller, B. 2017. Rapid turnover of effectors in grass powdery mildew (Blumeria graminis). BMC Evol. Biol. 17:223.

Michielse, C. B., Hooykaas, P. J., van den Hondel, C. A., and Ram, A. F. 2008. Agrobacterium-mediated transformation of the filamentous fungus Aspergillus awamori. Nat. Protoc. 3:1671-1678.

Nakagawa, T., Kurose, T., Hino, T., Tanaka, K., Kawamukai, M., Niwa, Y., Toyooka, K., Matsuoka, K., Jinbo, T., and Kimura, T. 2007. Development of series of gateway binary vectors, pGWBs, for realizing efficient construction of fusion genes for plant transformation. J. Biosci. Bioeng. 104:34-41.

Nowara, D., Gay, A., Lacomme, C., Shaw, J., Ridout, C., Douchkov, D., Hensel, G., Kumlehn, J., and Schweizer, P. 2010. HIGS: Host-induced gene silencing in the obligate biotrophic fungal pathogen Blumeria graminis. Plant Cell 22:3130-3141.

Nunes, C. C., and Dean, R. A. 2012. Host-induced gene silencing: A tool for understanding fungal host interaction and for developing novel disease control strategies. Mol. Plant Pathol. 13:519-529.

Odorizzi, G. 2006. The multiple personalities of Alix. J. Cell Sci. 119: 3025-3032.

Okudaira, S., Yukiura, H., and Aoki, J. 2010. Biological roles of lysophosphatidic acid signaling through its production by autotaxin. Biochimie 92:698-706.

Opalski, K. S., Schultheiss, H., Kogel, K. H., and Hückelhoven, R. 2005. The receptor-like MLO protein and the RAC/ROP family G-protein RACB modulate actin reorganization in barley attacked by the biotrophic powdery mildew fungus Blumeria graminis f. sp. hordei. Plant J. 41:291-303.

Pashkova, N., Gakhar, L., Winistorfer, S. C., Sunshine, A. B., Rich, M., Dunham, M. J., Yu, L., and Piper, R. C. 2013. The yeast Alix homolog Bro1 functions as a ubiquitin receptor for protein sorting into multivesicular endosomes. Dev. Cell 25:520-533.

Passon, D. M., Lee, M., Rackham, O., Stanley, W. A., Sadowska, A., Filipovska, A., Fox, A. H., and Bond, C. S. 2012. Structure of the heterodimer of human NONO and paraspeckle protein component 1 and analysis of its role in subnuclear body formation. Proc. Natl. Acad. Sci. U.S.A. 109:4846-4850.

Pedersen, C., Ver Loren van Themaat, E., McGuffin, L. J., Abbott, J. C., Burgis, T. A., Barton, G., Bindschedler, L. V., Lu, X., Maekawa, T., Wessling, R., Cramer, R., Thordal-Christensen, H., Panstruga, R., and Spanu, P. D. 2012. Structure and evolution of barley powdery mildew effector candidates. BMC Genomics 13:694.

Pennington, H. G., Gheorghe, D. M., Damerum, A., Pliego, C., Spanu, P. D., Cramer, R., and Bindschedler, L. V. 2016. Interactions between the powdery mildew effector BEC1054 and barley proteins identify candidate host targets. J. Proteome Res. 15:826-839.

Pennini, M. E., Perrinet, S., Dautry-Varsat, A., and Subtil, A. 2010. Histone methylation by NUE, a novel nuclear effector of the intracellular pathogen Chlamydia trachomatis. PLoS Pathog. 6:e1000995.

Petersen, T. N., Brunak, S., von Heijne, G., and Nielsen, H. 2011. SignalP 4.0: Discriminating signal peptides from transmembrane regions. Nat. Methods 8:785-786.

Pliego, C., Nowara, D., Bonciani, G., Gheorghe, D. M., Xu, R., Surana, P., Whigham, E., Nettleton, D., Bogdanove, A. J., Wise, R. P., Schweizer, P., Bindschedler, L. V., and Spanu, P. D. 2013. Host-induced gene silencing in barley powdery mildew reveals a class of ribonuclease-like effectors. Mol. Plant-Microbe Interact 26:633-642.

Pogorelko, G., Lionetti, V., Bellincampi, D., and Zabotina, O. 2013. Cell wall integrity: Targeted post-synthetic modifications to reveal its role in plant growth and defense against pathogens. Plant Signal. Behav. 8: e25435.

Rayon, C., Lerouge, P., and Faye, L. 1998. The protein $N$-glycosylation in plants. J. Exp. Bot. 49:1463-1472.

Rolando, M., Sanulli, S., Rusniok, C., Gomez-Valero, L., Bertholet, C., Sahr, T., Margueron, R., and Buchrieser, C. 2013. Legionella pneumophila effector RomA uniquely modifies host chromatin to repress gene expression and promote intracellular bacterial replication. Cell Host Microbe 13:395-405.

Romero, D., Eugenia Rivera, M., Cazorla, F. M., Codina, J. C., Fernández-Ortuño, D., Torés, J. A., Pérez-García, A., and de Vicente, A. 2008. Comparative histochemical analyses of oxidative burst and cell wall reinforcement in compatible and incompatible melonpowdery mildew (Podosphaera fusca) interactions. J. Plant Physiol. 165:1895-1905.

Roy, A., Kucukural, A., and Zhang, Y. 2010. I-TASSER: A unified platform for automated protein structure and function prediction. Nat. Protoc. 5: 725-738. 
Sampson, S. L. 2011. Mycobacterial PE/PPE proteins at the host-pathogen interface. Clin. Dev. Immunol. 2011:497203.

Sanford, J. C. 1990. Biolistic plant transformation. Physiol. Plant. 79: 206-209.

Schmidt, S. M., Kuhn, H., Micali, C., Liller, C., Kwaaitaal, M., and Panstruga, R. 2014. Interaction of a Blumeria graminis $\mathrm{f}$. sp. hordei effector candidate with a barley ARF-GAP suggests that host vesicle trafficking is a fungal pathogenicity target. Mol. Plant Pathol. 15: 535-549.

Silmon de Monerri, N. C., and Kim, K. 2014. Pathogens hijack the epigenome: A new twist on host-pathogen interactions. Am. J. Pathol. 184:897-911.

Souza, C. A., Li, S., Lin, A. Z., Boutrot, F., Grossmann, G., Zipfel, C., and Somerville, S. C. 2017. Cellulose-derived oligomers act as damage-associated molecular patterns and trigger defense-like response. Plant Physiol. 173: 2383-2398.

Spanu, P. D., Abbott, J. C., Amselem, J., Burgis, T. A., Soanes, D. M., Stüber, K., Ver Loren van Themaat, E., Brown, J. K., Butcher, S. A., Gurr, S. J., Lebrun, M.-H., Ridout, C. J., Schulze-Lefert, P., Talbot, N. J., Ahmadinejad, N., Ametz, C., Barton, G. R., Benjdia, M., Bidzinski, P., Bindschedler, L. V., Both, M., Brewer, M. T., Cadle-Davidson, L., CadleDavidson, M. M., Collemare, J., Cramer, R., Frenkel, O., Godfrey, D., Harriman, J., Hoede, C., King, B. C., Klages, S., Kleemann, J., Knoll, D., Koti, P. S., Kreplak, J., López-Ruiz, F. J., Lu, X., Maekawa, T., Mahanil, S., Micali, C., Milgroom, M. G., Montana, G., Noir, S., O’Connell, R. J., Oberhaensli, S., Parlange, F., Pedersen, C., Quesneville, H., Reinhardt, R., Rott, M., Sacristán, S., Schmidt, S. M., Schön, M., Skamnioti, P., Sommer, H., Stephens, A., Takahara, H., Thordal-Christensen, H., Vigouroux, M., Wessling, R., Wicker, T., and Panstruga, R. 2010. Genome expansion and gene loss in powdery mildew fungi reveal tradeoffs in extreme parasitism. Science 330:1543-1546.

Stebbins, C. E., and Galán, J. E. 2001. Structural mimicry in bacterial virulence. Nature 412:701-705.

Thordal-Christensen, H., Zhang, Z., Wei, Y., and Collinge, D. B. 1997. Subcellular localization of $\mathrm{H}_{2} \mathrm{O}_{2}$ in plants. $\mathrm{H}_{2} \mathrm{O}_{2}$ accumulation in papillae and hypersensitive response during the barley-powdery mildew interaction. Plant J. 11:1187-1194.

Underwood, W., and Somerville, S. C. 2008. Focal accumulation of defences at sites of fungal pathogen attack. J. Exp. Bot. 59:3501-3508.

Vallarino, J. G., and Osorio, S. 2012. Signaling role of oligogalacturonides derived during cell wall degradation. Plant Signal. Behav. 7:1447-1449.

Vela-Corcía, D., Bautista, R., de Vicente, A., Spanu, P. D., and PérezGarcía, A. 2016. De novo analysis of the epiphytic transcriptome of the cucurbit powdery mildew fungus Podosphaera xanthii and identification of candidate secreted effector proteins. PLoS One 11:e0163379.

Vela-Corcía, D., Bellón-Gómez, D., López-Ruiz, F., Torés, J. A., and PérezGarcía, A. 2014. The Podosphaera fusca TUB2 gene, a molecular "Swiss Army knife" with multiple applications in powdery mildew research. Fungal Biol. 118:228-241.

Vela-Corcía, D., Romero, D., Torés, J. A., De Vicente, A., and PérezGarcía, A. 2015. Transient transformation of Podosphaera xanthii by electroporation of conidia. BMC Microbiol. 15:20.

Viaud, J., Boal, F., Tronchère, H., Gaits-Iacovoni, F., and Payrastre, B. 2014. Phosphatidylinositol 5-phosphate: A nuclear stress lipid and a tuner of membranes and cytoskeleton dynamics. BioEssays 36:260-272.
Vidhyasekaran, P. 1997. Fungal Pathogenesis in Plants and Crops. Molecular Biology and Host Defense Mechanisms. Marcel Dekker, New York.

Wass, M. N., Kelley, L. A., and Sternberg, M. J. 2010. 3DLigandSite: Predicting ligand-binding sites using similar structures. Nucleic Acids Res. 38 (Supp 2):W469-W473.

Weßling, R., Epple, P., Altmann, S., He, Y., Yang, L., Henz, S. R., McDonald, N., Wiley, K., Bader, K. C., Gläßer, C., Mukhtar, M. S., Haigis, S., Ghamsari, L., Stephens, A. E., Ecker, J. R., Vidal, M., Jones, J. D., Mayer, K. F., Ver Loren van Themaat, E., Weigel, D., SchulzeLefert, P., Dangl, J. L., Panstruga, R., and Braun, P. 2014. Convergent targeting of a common host protein-network by pathogen effectors from three kingdoms of life. Cell Host Microbe 16:364-375.

Wicker, T., Oberhaensli, S., Parlange, F., Buchmann, J. P., Shatalina, M., Roffler, S., Ben-David, R., Doležel, J., Šimková, H., Schulze-Lefert, P., Spanu, P. D., Bruggmann, R., Amselem, J., Quesneville, H., Ver Loren van Themaat, E., Paape, T., Shimizu, K. K., and Keller, B. 2013. The wheat powdery mildew genome shows the unique evolution of an obligate biotroph. Nat. Genet. 45:1092-1096.

Yang, J., Roy, A., and Zhang, Y. 2013. Protein-ligand binding site recognition using complementary binding-specific substructure comparison and sequence profile alignment. Bioinformatics 29:2588-2595.

Yap, H. Y., Chooi, Y. H., Fung, S. Y., Ng, S. T., Tan, C. S., and Tan, N. H 2015. Transcriptome analysis revealed highly expressed genes encoding secondary metabolite pathways and small cysteine-rich proteins in the sclerotium of Lignosus rhinocerotis. PLoS One 10:e0143549.

Zhai, Q., Landesman, M. B., Robinson, H., Sundquist, W. I., and Hill, C. P. 2011. Identification and structural characterization of the ALIX-binding late domains of simian immunodeficiency virus $\operatorname{SIV}_{\operatorname{mac} 239}$ and SIV $_{\text {agmTan-1. J. Virol. 85:632-637. }}$

Zhang, W. J., Pedersen, C., Kwaaitaal, M., Gregersen, P. L., Mørch, S. M., Hanisch, S., Kristensen, A., Fuglsang, A. T., Collinge, D. B., and Thordal-Christensen, H. 2012. Interaction of barley powdery mildew effector candidate CSEP0055 with the defence protein PR17c. Mol. Plant Pathol. 13:1110-1119.

Zhang, Y. 2008. I-TASSER server for protein 3D structure prediction. BMC Bioinformatics 9:40.

Zhou, J., Lin, C. Z., Zheng, X. Z., Lin, X. J., Sang, W. J., Wang, S. H., Wang, Z. H., Ebbole, D., and Lu, G. D. 2009. Functional analysis of an $\alpha-1,2$-mannosidase from Magnaporthe oryzae. Curr. Genet. 55:485496.

\section{AUTHOR-RECOMMENDED INTERNET RESOURCES}

3DLigandSite: http://www.sbg.bio.ic.ac.uk/3dligandsite CATH/Gene3D: http://www.cathdb.info COACH: http://zhanglab.ccmb.med.umich.edu/COACH ExPASy portal: http://www.expasy.org

GalaxySite: http://galaxy.seoklab.org/cgi-bin/submit.cgi?type=SITE

I-TASSER, a server for protein structure and function predictions: http://zhanglab.ccmb.med.umich.edu/I-TASSER

Motif Scan: http://myhits.isb-sib.ch/cgi-bin/motif_scan

The National Center of Biotechnology Information website: http://www.ncbi.nlm.nih.gov

Phyre2: http://www.sbg.bio.ic.ac.uk/ phyre2/html/page.cgi?id=index 